\title{
Faults in the Asquempont area, southern Brabant Massif, Belgium
}

\author{
T.N. Debacker ${ }^{1}$, A. Herbosch ${ }^{2}$, J. Verbiers ${ }^{3} \&$ M. Sintubin ${ }^{1}$ \\ ${ }^{1}$ Structural Geology \& Tectonics Group, Katholieke Universiteit Leuven, Redin- \\ genstraat 16,B-3000 Leuven, timothy.debacker@geo.kuleuven.ac.be, \\ manuel.sintubin@geo.kuleuven.ac.be. \\ ${ }^{2}$ Département des Sciences de la Terre et de l'environnement, Université Libre de \\ Bruxelles, Avenue F. Roosevelt 50 CP160/02, B-1050 Bruxelles, \\ herbosch@ulb.ac.be \\ ${ }^{3}$ Laboratory of Palaeontology, Ghent University, Krijgslaan 281, S8, B-9000 \\ Gent, jacques.verniers@rug.ac.be \\ ${ }^{1}$ (corresponding author)
}

Manuscript received: October 2002; accepted: September 2003

\begin{abstract}
The literature suggests that the Asquempont fault, a supposedly important reverse fault forming the limit between the Lower to lower Middle Cambrian and the Ordovician in the Sennette valley, is poorly understood. Nevertheless, this fault is commonly equated with a pronounced NW-SE-trending aeromagnetic lineament, the Asquempont lineament, and both the geometry of the Asquempont lineament and the supposed reverse movement of the Asquempont fault are used to develop large-scale tectonic models of the Brabant Massif. New outcrop observations in the Asquempont area, the "type locality" of the Asquempont fault, in combination with outcrop and borehole data from surrounding areas, show that the Asquempont fault is not an important reverse fault, but instead represents a pre-cleavage, low-angle extensional detachment. This detachment formed between the Caradoc and the timing of folding and cleavage development and is not related to the aeromagnetic Asquempont lineament. The Asquempont area also contains several relatively important, steep, post-cleavage normal faults. Apparently, these occur in a WNW-ESE-trending zone between Asquempont and Fauquez, extending westward over Quenast towards Bierghes. This zone coincides with the eastern part of the WNW-ESE-trending Nieuwpoort-Asquempont fault zone, for which, on the basis of indirect observations, previously a strike-slip movement has been proposed. Our outcrop observations question this presumed strike-slip movement. The Asquempont fault may be related to the progressive unroofing of the core of the Brabant Massif from the Silurian onwards. Possibly, other low-angle extensional detachments similar to the Asquempont fault occur in other parts of the massif. Possible candidates are the paraconformity-like contacts depicted on the most recent geological map of the Brabant Massif.
\end{abstract}

Keywords: Anglo-Brabant fold belt, Lower Palaeozoic, extensional detachment, normal faults

The low-grade Lower Palaeozoic Brabant Massif (Fig. 1) forms the southeastern part of the largely concealed Anglo-Brabant deformation belt, one of the deformation belts of eastern Avalonia. An angular unconformity separates the deformed Lower Palaeozoic deposits of the massif from overlying relatively undeformed, diagenetic, Middle Devonian continental deposits (Fourmarier, 1914, 1921; Legrand, 1967; De Vos et al., 1993a; Van Grootel et al., 1997). There is only evidence for a single progressive deformation, currently considered to have taken place from the early Silurian to the latest Early Devonian, possibly continuing into the Eifelian (Debacker, 2001; Verniers et al., 2002; Debacker et al., 2002).

Outcrops in the Brabant Massif are scarce. Only in the southern part of the massif, small rivers cut through the overlying Mesozoic and Cenozoic deposits, thus allowing a direct observation of the Lower 


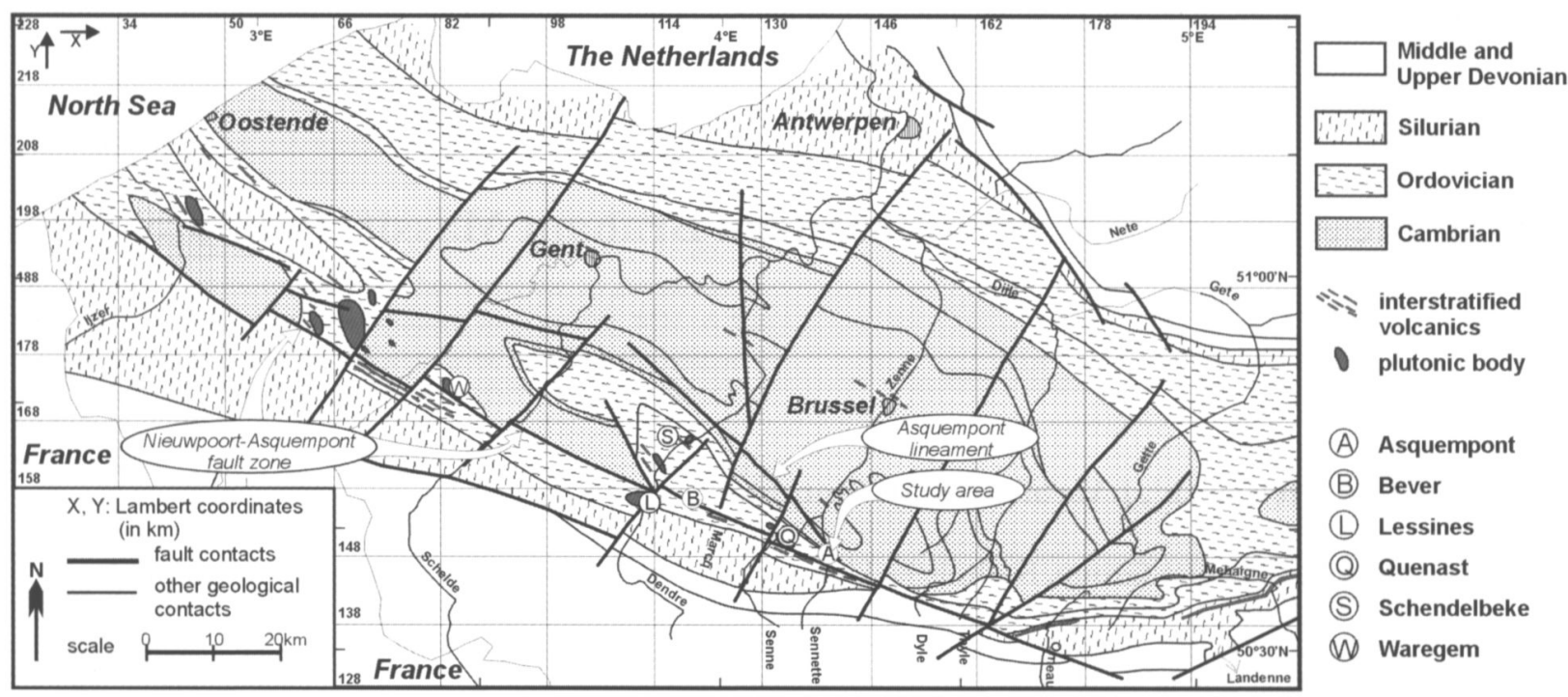

Fig. 1. Geological subcrop map of the Brabant Massif (after De Vos et al., 1993a and Van Grootel et al., 1997) showing the position of the study area, the Asquempont lineament and several outcrop and borehole localities used in this study (Asquempont, Bever, Lessines, Quenast, Schendelbeke, Waregem). Note that the Asquempont lineament, depicted as an unnamed fault on the map of De Vos et al. (1993a) on the basis of aeromagnetic data, only recently received its name (Sintubin \& Everaerts, 2002).

Palaeozoic rocks. Because of the poor degree of exposure, the architecture of the core of the massif is still under debate. To overcome this problem, during the last decade much attention has been paid to geophysical data. High-quality aeromagnetic maps (Chacksfield et al., 1993; De Vos et al., 1993b; Belgian Geological Survey, 1994) show the centre of the Brabant Massif as an aeromagnetic high, attributed to the magnetite-bearing lowermost Cambrian Tubize Formation (de Magnée \& Raynaud, 1944; Chacksfield et al., 1993; De Vos et al., 1992, 1993a). The southwestern limit of this aeromagnetic high is formed by a pronounced NNW-SSE-trending aeromagnetic lineament, currently termed the Asquempont lineament (Fig. 1; Sintubin \& Everaerts, 2002). On the basis of the apparent coincidence in the Asquempont area between the outcrop trace of the Asquempont fault depicted by Legrand (1967) and the trace of the Asquempont lineament, several researchers attributed this aeromagnetic lineament to the Asquempont fault (e.g. Sintubin et al., 1998; Sintubin, 1997b, 1999; Debacker, 1999; Mansy et al., 1999). In addition, since Legrand (1967) defined the Asquempont fault as an important NE-dipping reverse fault (cf. Hennebert \& Eggermont, 2002), many authors also consider the aeromagnetic Asquempont lineament as an important reverse fault and have used this idea to develop large-scale tectonic models for the Brabant Massif (e.g. De Vos et al., 1993a; Sterpin \& De Vos, 1996; Everaerts et al., 1996; De Vos, 1997; Sintubin et al., 1998; Sintubin, 1997b, 1999; Mansy et al., 1999).

However, from the literature it appears that the
Asquempont fault was never properly examined, the fault kinematics are not understood, the age is uncertain, and even its orientation is not clear. From the 19th century onwards geologists have attributed the stratigraphic gap between the Lower to lower Middle Cambrian Oisquercq Formation and the lower Tremadoc Chevlipont Formation in the Asquempont-Virginal area, Sennette valley, to the activity of an important fault (Fig. 2). Both Dumont (1848) and Malaise $(1873,1908)$ mention an abrupt, tectonic contact between the Cambrian and the Ordovician. According to Fourmarier (1914, 1921), however, there is no evidence for a tectonic contact in the Asquempont-Virginal area. Without presenting any evidence, Mortelmans (1955) puts forward an important $\mathrm{N}$-dipping thrust in the same area and labels it the Virginal fault. Following the construction of the new Brussels-Charleroi canal, Legrand (1967) changes the name of this fault to Asquempont fault. $\mathrm{He}$ describes it as a steeply $\mathrm{N}$-dipping zone, with extensive brecciations and numerous quartz veins, forming the limit between the Oisquercq Formation and the Chevlipont Formation and, without clear arguments, puts forward a reverse movement with a sinistral component. To date, this is still the most extensive, and most used (e.g. Hennebert \& Eggermont, 2002), description of this fault. However, although in the Asquempont area the limit between the Oisquercq Formation and the Chevlipont Formation was attributed to this supposedly important fault (Fig. 2), in other outcrops several researchers claim to have observed a gradual transition or a conformable 


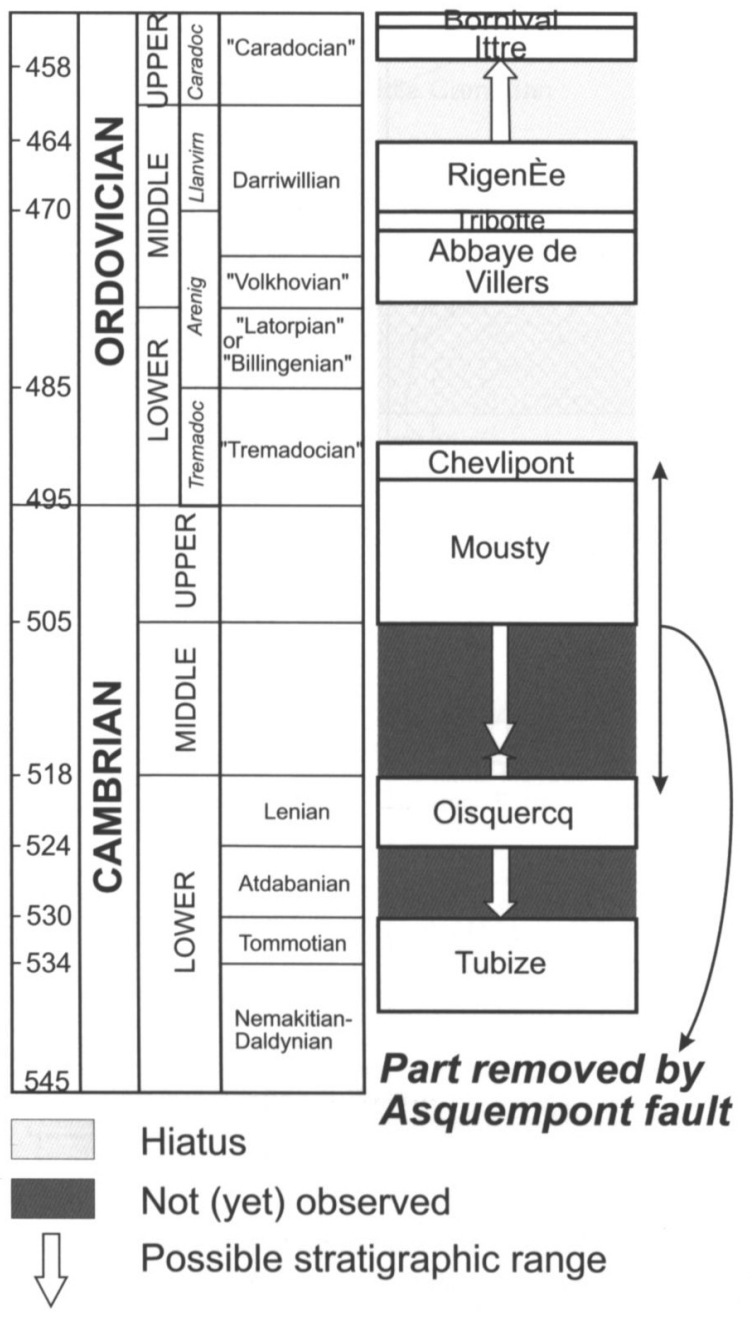

Fig. 2. Synthetic chart of the chronostratigraphical position of the formations mentioned in this paper, taken from Verniers et al. (2001). The absolute time-scale is that of Gradstein \& Ogg (1996). In the Sennette valley, the Asquempont fault juxtaposes the Chevlipont Formation and the Oisquercq Formation, hereby removing the Mousty Formation and parts of the former two formations.

contact between both formations (e.g. Fourmarier, 1914, 1921; Vanguestaine, 1977; Lenoir, 1987; Servais $e t$ al., 1993), whereas in the Lessines borehole, in the Dendre valley, this contact appears to be formed by a microconglomerate (Herbosch et al., 1991; Vanguestaine, 1991). These observations are difficult to reconcile with the idea of an important fault structure.

In this paper the Asquempont fault is described and re-defined in its 'type locality'. These new observations are linked with observations from other outcrop areas and boreholes and finally the data are compared with aeromagnetic data. This results in an entirely different image than that based on the original description of Legrand (1967).

\section{Geological setting}

The Asquempont-Virginal area is situated in the Sennette valley, in the southern part of the Brabant Massif, $25 \mathrm{~km}$ to the SSW of Brussels (Fig. 1). The Asquempont fault occurs in the sub-vertical northern limb of a hectometre-scale synform with a step foldlike geometry and a S-verging asymmetry (the Asquempont synform; Debacker et al., 2001). Throughout the study area, cleavage dips moderately to steeply towards the NE and generally shows a small-angle divergent cleavage fanning across the folds. The cleavage/bedding intersection and fold hinge lines are sub-horizontal to gently plunging (Fig. 3). A small angle axial cleavage transection is common (sensu Johnson, 1991), the sense of which may vary from fold to fold. This variation in sense and amount of cleavage transection, in combination with the small changes in fold hinge line orientation, may be attributed to a periclinal fold shape (cf. Debacker et al., 1999). As in the other outcrop areas of the Brabant Massif (Sintubin, 1997a, 1999; Sintubin et al., 1998; Debacker et al., 1999, 2001; Debacker, 1999, 2001, 2002; Belmans, 2000) tectonic folding is cogenetic with cleavage development.

The outcrops in the Asquempont-Virginal area can be combined into three large sections, thus enabling a study of the lateral prolongation of the deformation

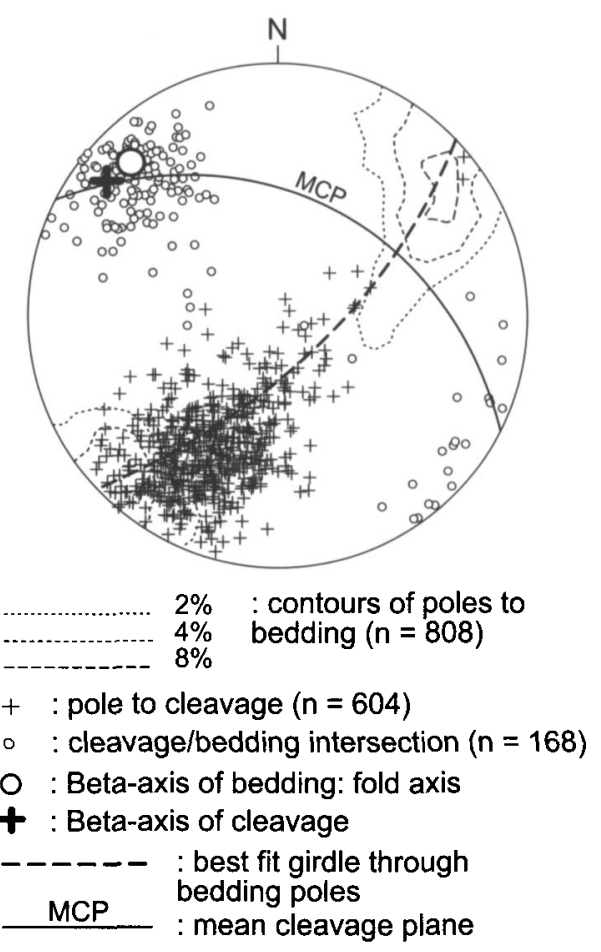

Fig. 3. Lower hemisphere equal area stereographic projection showing bedding, cleavage and cleavage/bedding intersection data from the Asquempont-Virginal area. The data are taken from outcrops labelled in figure 4 . 


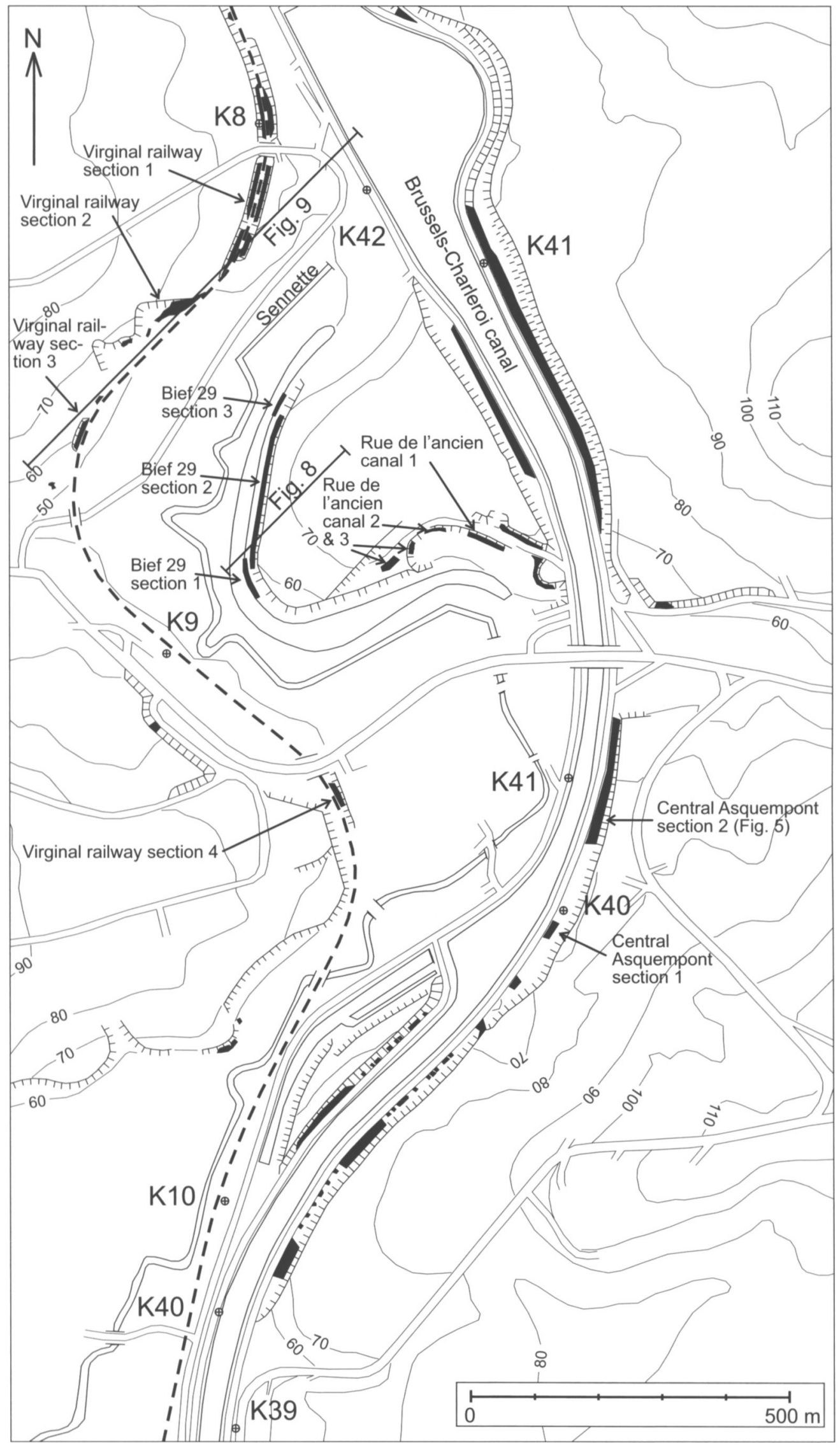

Fig. 4. Location of outcrops in the Asquempont-Virginal area, marked in black. Only those mentioned in the present study are labelled. Also shown are the positions of the section line along the Bief 29 section (Fig. 8) and of the section line along the Virginal railway section (Fig. 9). 

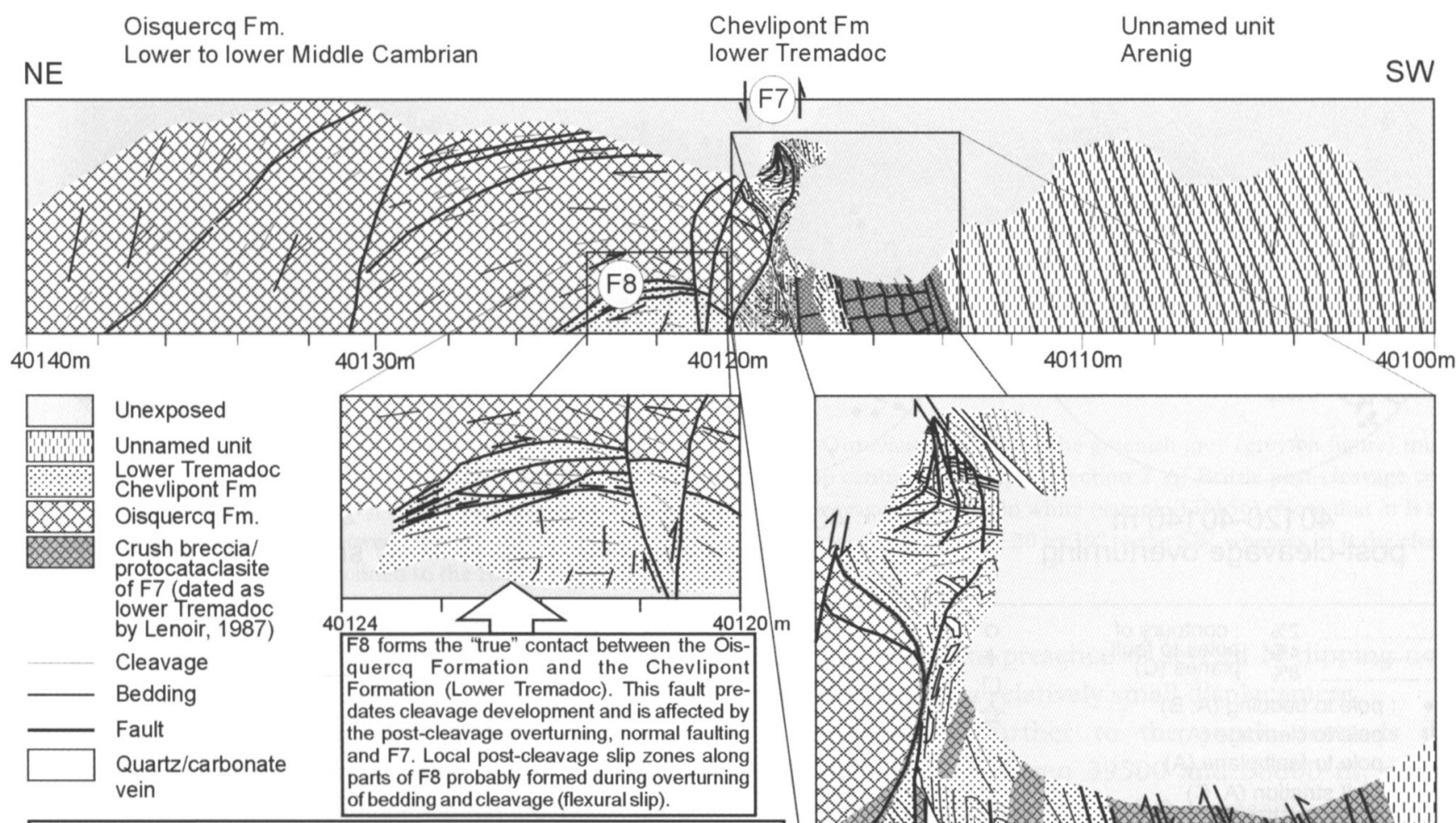

F7: semi-ductile to brittle post-cleavage fault zone, truncating F8 and as such only apparently forming the Cambrian-Ordovician contact. F7 testifies of several episodes of movement, the early episodes accompanied by fold development, the later episodes by mainly brittle deformation. Note that although the fault rock is dated as lower Tremadoc by means of acritarchs (Lenoir, 1987), the lithological aspects characteristic of the lower Tremadoc Chevlipont Formation are not observed in this fault zone.

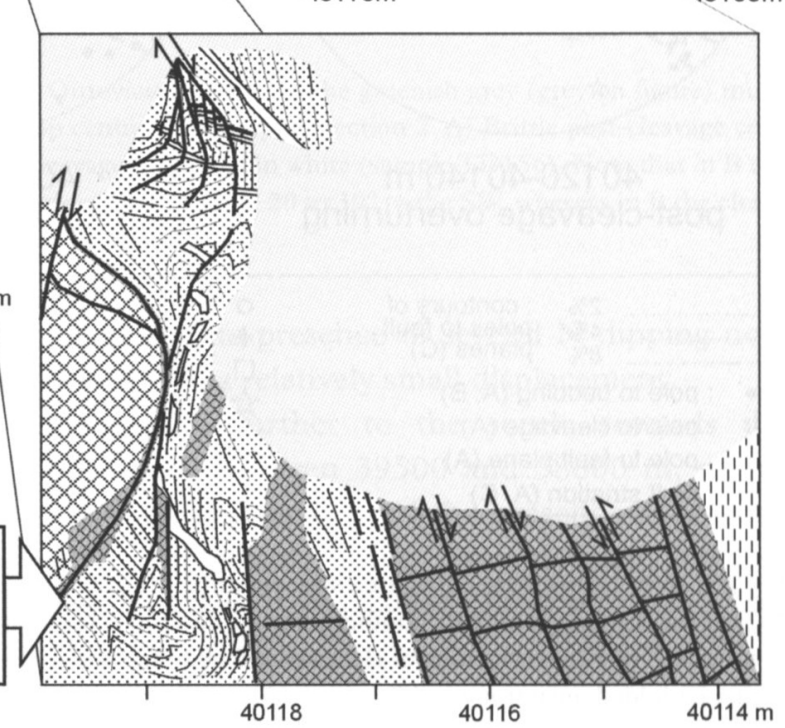

Fig. 5. The classical outcrop of the Asquempont fault (Legrand, 1967), in the southern part of outcrop central Asquempont section 2, along the central Asquempont section, after removal of debris and vegetation. See text for explanation and figure 4 for location. Distances, expressed in metres, are based on kilometre posts along the E-side of the canal.

related to and surrounding the Asquempont fault (Fig. 4). The classical outcrop of this fault, as described by Legrand (1967), along the E-side of the new Brussel-Charleroi canal, forms part of the central Asquempont section. The Bief 29 section is composed of outcrops along the eastern side of an isolated part of the old (i.e. pre-1962) Brussel-Charleroi canal. The Virginal railway section (cf. Mortelmans, 1955) consists of outcrops along an abandoned railway to the NW of the Bief 29 section and the central Asquempont section.

Seven different formations occur in the study area, the youngest being the middle Caradoc Bornival Formation, the oldest the Lower to lower Middle Cambrian Oisquercq Formation. A detailed description of the different formations can be found in Verniers et al. (2001).

\section{Macroscopic observations}

The central Asquempont section 2: the classical outcrop of the Asquempont fault

Distances along this outcrop are expressed in metres along the E-side of the canal, from Charleroi to Brussels. At the time of this study, the outcrop was covered with vegetation and debris. Removal of this cover showed that, even on the basis of geometry alone, this outcrop contains much more information and is more complex than what is presented by Legrand (1967). At least three large structural elements can be distinguished (Fig. 5).

\section{Antiformal structure north of the fault zone}

Between 40140 and $40120 \mathrm{~m}$ the cleavage in the Oisquercq Formation is deformed into a sub-horizontal to gently NW-plunging open antiformal structure (Fig. 5, Fig. 6A). Where observable, bedding orientations show that the angle between bedding and cleavage remains the same $\left(32 \pm 10^{\circ}\right)$. As such, this deformation post-dates the cleavage-related tectonic folding. Several small reverse faults occur, sub-parallel to the cleavage, with a direction of displacement oriented perpendicular to the axis of the antiformal structure. Where present, the fault material is a crush breccia to protocataclasite.

The antiformal structure and the cleavage-parallel 


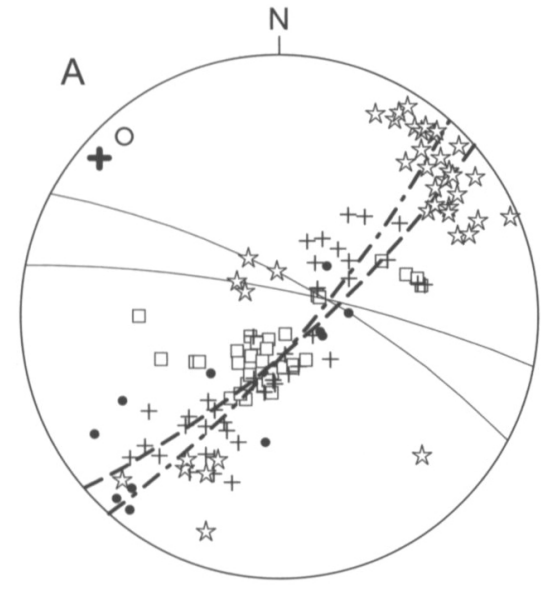

40120-40140 m post-cleavage overturning

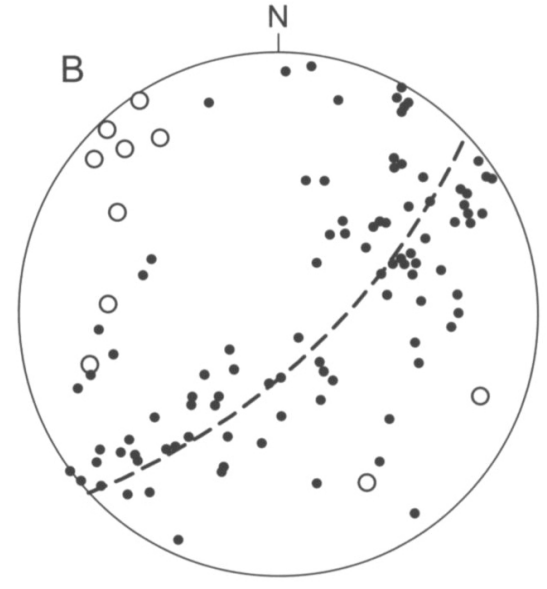

$40114-40120 \mathrm{~m}$ folded anisotropy in F7

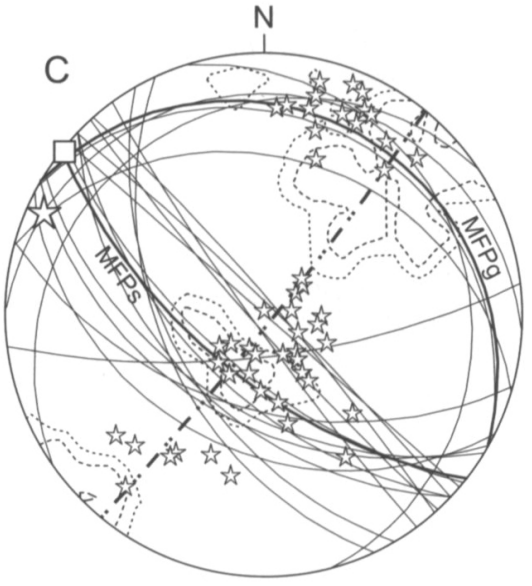

40114-40120 m small faults in F7

\begin{tabular}{|c|c|c|c|}
\hline 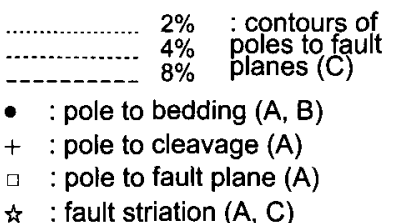 & 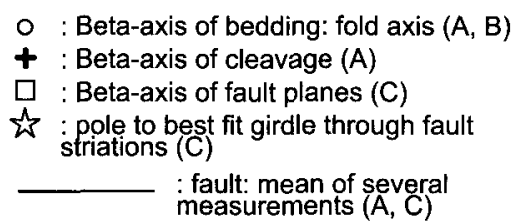 & $\begin{array}{l}\text { MFPg/MFPs } \\
------ \\
-\cdot-\cdot-\cdot- \\
-\cdot-\cdots-\cdot .\end{array}$ & $\begin{array}{l}\text { : mean orientation of gently/ } \\
\text { steeply dipping faults in } F 7(C) \\
\text { : best fit girdle through bedding } \\
\text { poles }(A, B) \\
\text { : best fit girdle through cleavage } \\
\text { poles }(A) \\
\text { : best fit girdle through poles to } \\
\text { fault planes }(C)\end{array}$ \\
\hline
\end{tabular}

Fig. 6. Lower hemisphere equal area stereographic projections of the semi-ductile and brittle post-cleavage deformation in the classical outcrop of the Asquempont fault, southern part of outcrop central Asquempont section 2 (cf. Fig. 5). A) deformation in the antiformal structure to the north of F7: overturning of cleavage and bedding, with bedding- and cleavage-parallel slip planes, affected by two small steeply dipping faults; B) folded anisotropy in F7, with fold axes trending sub-parallel to the trend of the fault zone; C) small faults within F7, of which the individual measurements are contoured and the mean orientations are shown as great circles. Note the predominantly dip-slip displacements along the faults and the sub-parallelism between the faults and the regional structural trend (cf. Fig. 3).

slip planes are cut by sub-vertical faults, with a small down-throw towards the south $(<0.5 \mathrm{~m})$, and a predominantly dip-slip displacement. The fault material is a fine crush breccia to protocataclasite. Towards the south (between 40118 and $40119.5 \mathrm{~m}$ ) this structure is truncated by the Asquempont fault sensu Legrand (1967).

\section{The Asquempont fault sensu Legrand (1967): F7}

Between 40119.5 and $40114 \mathrm{~m}$ a very distinct, subvertical to steeply dipping quartz vein-rich zone of intense deformation occurs (Fig. 5), apparently separating the Oisquercq Formation (greenish grey mudstone) from the upper Arenig unnamed unit of the Abbaye de Villers Formation (black mudstone to blue-grey fine sandstone) (Verniers et al., 2001; Samuelsson \& Verniers, 2000). The black to dark grey rocks inside the deformation zone yielded a biostratigraphic age of early Tremadoc (acritarchs) and are considered to belong to the Chevlipont Formation (Lenoir, 1987). It should be mentioned, however, that, due to the deformation, sedimentological features characteristic of the Chevlipont Formation cannot be observed inside the deformation zone and that, lithologically, the deformed rocks may belong to any formation predominantly composed of black to grey mudstone to siltstone.

A very distinct sub-vertical to steeply dipping foliation is present, predominantly along the $\mathrm{N}$-side of the fault zone. This foliation is deformed into numerous centimetre- to decimetre-scale folds, with sub-horizontal to moderately plunging hinge lines, trending parallel to the fault zone (Fig. 5, Fig. 6B). A dark protocataclasite to cataclasite is present in the central and southern part of the fault, locally containing millimetric zones of ultracataclasite, cut by at least two sets of small normal faults (Fig. 5, Fig. 6C). Centimetre to decimetre-thick quartz veins cross-cut the small folds and the (proto-)cataclasite in the central parts of the fault zone. In turn, the veins are deformed by small, steeply SW-dipping normal faults (Fig. 5, Fig. $6 \mathrm{C})$. In the middle and upper part of the outcrop, the dark bluish grey to black Ordovician rocks are separated from the pale, greenish grey overturned rocks of the Oisquercq Formation by a $5 \mathrm{~cm}$-thick protocataclasite to cataclasite (Fig. 7A). Although this seems compatible with the description of Legrand (1967), observations in the lower part of the outcrop show that this is not the original contact between the Lower to lower Middle Cambrian and the Ordovician. 

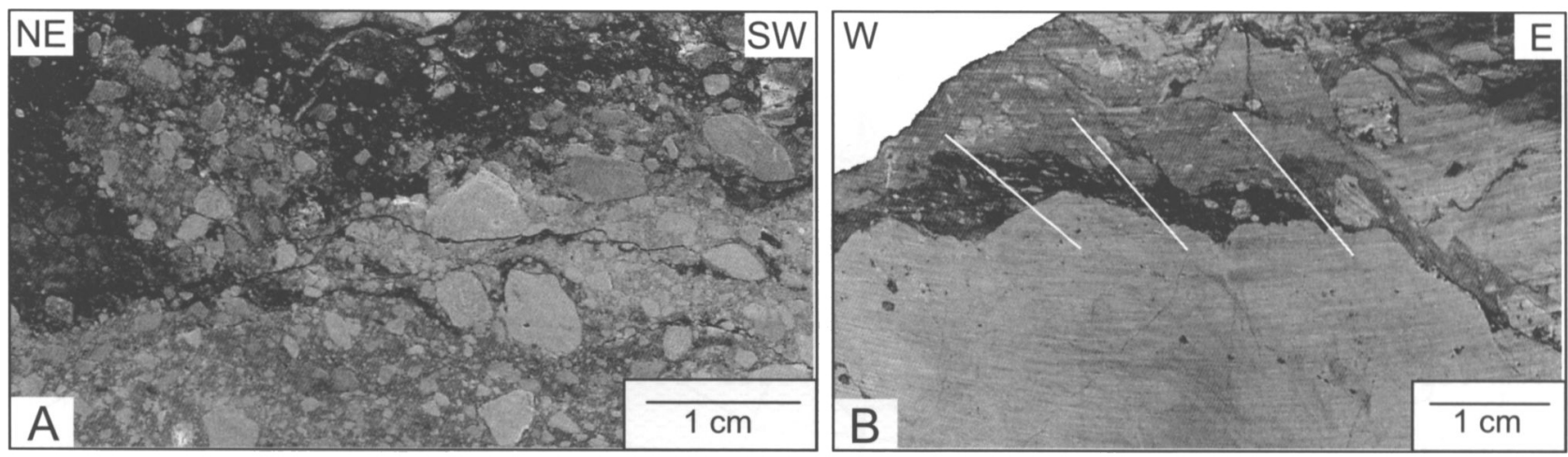

Fig. 7. Two different types of tectonic contacts between the dark grey to black Ordovician rocks and the greenish grey (grey on figure) mudstone of the Lower to lower Middle Cambrian Oisquercq Formation in outcrop central Asquempont section 2. A) Brittle post-cleavage contact formed by F7 (sample TD147); B) pre-cleavage contact: the trace of the cleavage is marked in white (sample TD156). Note that in B the cleavage crosscuts the contact between the two different lithologies. The long side of $\mathrm{A}$ is inclined 20 to $30^{\circ}$ to the $\mathrm{SW}$, whereas in $\mathrm{B}$ the cleavage is sub-horizontal to gently inclined to the $\mathrm{E}$.

\section{The contact between the Cambrian and the Ordovician: F8}

In the lower part of the outcrop, between 40120 and $40125 \mathrm{~m}$, in the antiformal overturned part, nonbrecciated deposits of the Chevlipont Formation occur, separated from the overlying overturned Oisquercq Formation by a $0.5-1 \mathrm{~m}$-thick zone (F8) consisting of lenses of the Chevlipont Formation and the Oisquercq Formation (Fig. 5). The contacts between the different lenses are usually sharp and welded and the cleavage remains undisturbed as it passes through them (Fig. 7B). This suggests a pre-cleavage origin. In this zone, several striation-bearing, cleavage-parallel slip surfaces are present. Since these also occur in the overlying overturned part of the Oisquercq Formation and post-date cleavage development they are not considered related to F8. Only at one locality in F8, a small infilled post-cleavage slip zone coincides with a contact between lenses of Cambrian and Ordovician rocks, suggesting a local reactivation of parts of F8.

This 'true' contact between the Oisquercq Formation and the Chevlipont Formation (F8) is, in turn, deformed into an antiformal structure and truncated by the large fault zone (F7) and the small sub-vertical normal faults.

\section{Normal faults south of F7}

Around $40085 \mathrm{~m}$ a steep, quartz vein-bearing, postcleavage semi-ductile to brittle deformation zone is present (F12), similar to F7. As argued by Legros (1991), the presence of the Abbaye de Villers Formation (including the unnamed unit) both to the north and to the south of this deformation zone suggests a relatively small displacement. Possibly this fault represents a splay of F7. In the densely covered slope between $40080 \mathrm{~m}$ and $39830 \mathrm{~m}$, the distribution of the Abbaye de Villers Formation and the Tribotte Forma- tion suggests the presence of several N-dipping normal faults with a relatively small displacement.

In addition, further to the south, towards the Fauquez area, between 39500 and $38000 \mathrm{~m}$, recent observations have evidenced the presence of several, relatively important, steep, post-cleavage normal faults (Debacker et al., 2001; Debacker, 2001; Van Grootel et al., 2002).

\section{The Bief 29 section}

Distances along the NE-side of this bend of the old canal are measured starting from the eastern extremity, closest to the bridge of Asquempont (see Fig. 4 for location). The $260 \mathrm{~m}$-long section shown in Fig. 8 comprises the Ittre Formation, the Rigenée Formation and the Abbaye de Villers Formation. The largest outcrop of the Ittre Formation (outcrop Bief 29 section 1) is a temporary outcrop, which only emerged during extremely low water levels caused by workings. The same accounts for the northernmost part of the $\mathrm{Ab}$ baye de Villers Formation (outcrop Bief 29 section 3).

\section{Large-scale kink band}

The most apparent feature of this section is a largescale sigmoidal change in cleavage dip (between 550 and $700 \mathrm{~m}$, Fig. 8). Apart from some brittle cleavageparallel slip surfaces, the zone with the lowest cleavage dip does not show evidence for strong shearing, nor does it reflect higher strains than the surrounding rocks. The structure is interpreted as a large-scale, $100 \mathrm{~m}$ wide kink band with steeply SW-dipping kink band boundaries (cf. Goscombe et al., 1994). The localised cleavage-parallel slip zones may result from flexural slip during kink band development.

\section{Faults}

A reverse moderately NE-dipping fault (F9) with, 


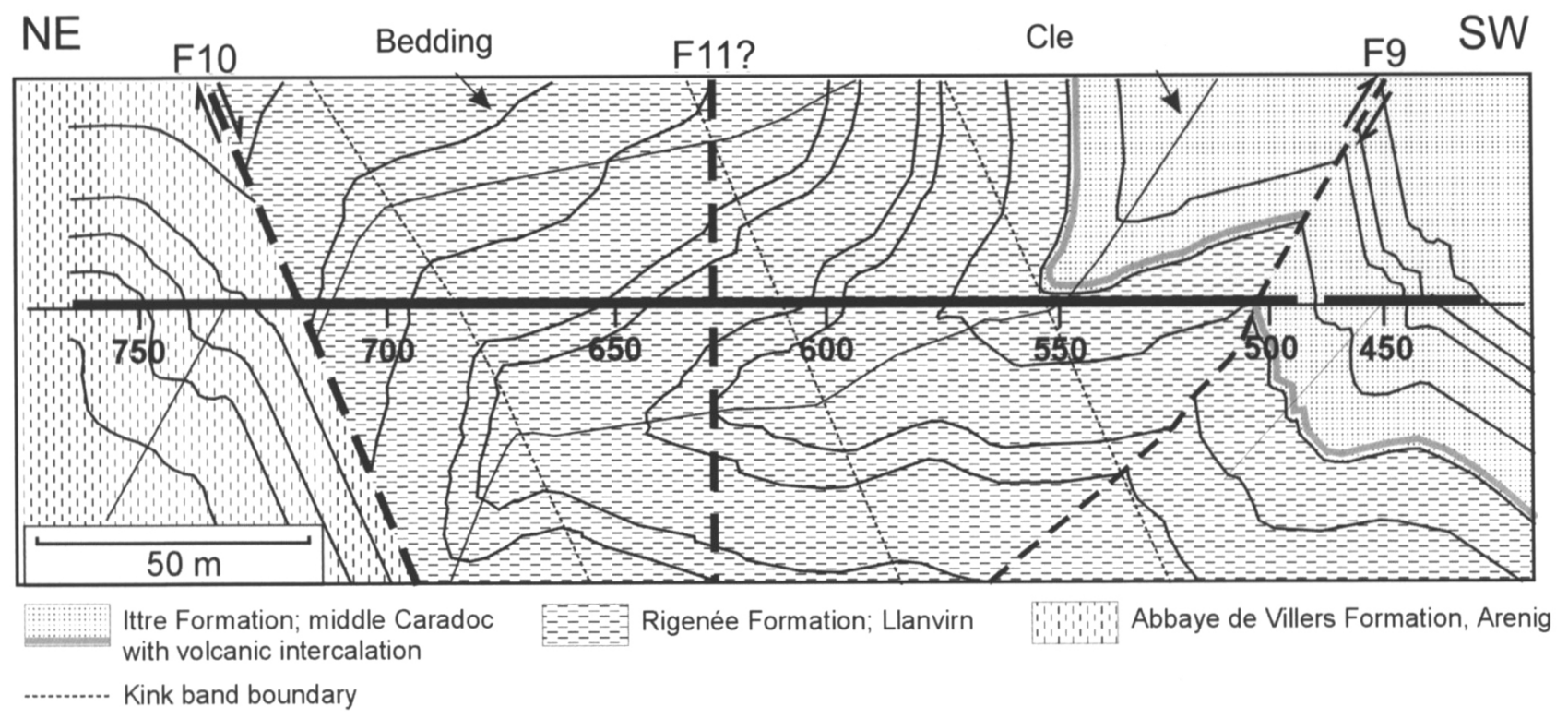

Fig. 8. Cross-section along the Bief 29 section (see Fig. 4 for section line). The projected distances are measured along the NE-side of the old canal (Bief 29), starting from its easternmost extremity. Note the large-scale sigmoidal change of cleavage and bedding. Outcrops are marked in black.

judging from the stratigraphy, a displacement of minimum 18 metres, separates the Ittre Formation from the Rigenée Formation. This fault, post-dating cleavage development, runs along the axial surface of a small antiform with a step fold-like geometry (Fig. 8). The Rigenée Formation, in turn, is separated from the Abbaye de Villers Formation by a wide, postcleavage fault zone (F10; Fig. 8), characterised by a semi-ductile deformation of the cleavage and a fine crush breccia to protocataclasite. The protocataclasite zones are cross-cut by numerous small faults, testifying of several episodes of movement. Striations on the fault planes indicate a dip-slip movement. Although the sense of slip could not always be determined on the fault surfaces, the steeply SW-dipping orientation of the faults, combined with the stratigraphic jump across this fault zone, implies a normal displacement, estimated at minimum $200 \mathrm{~m}$. A similar fault zone is

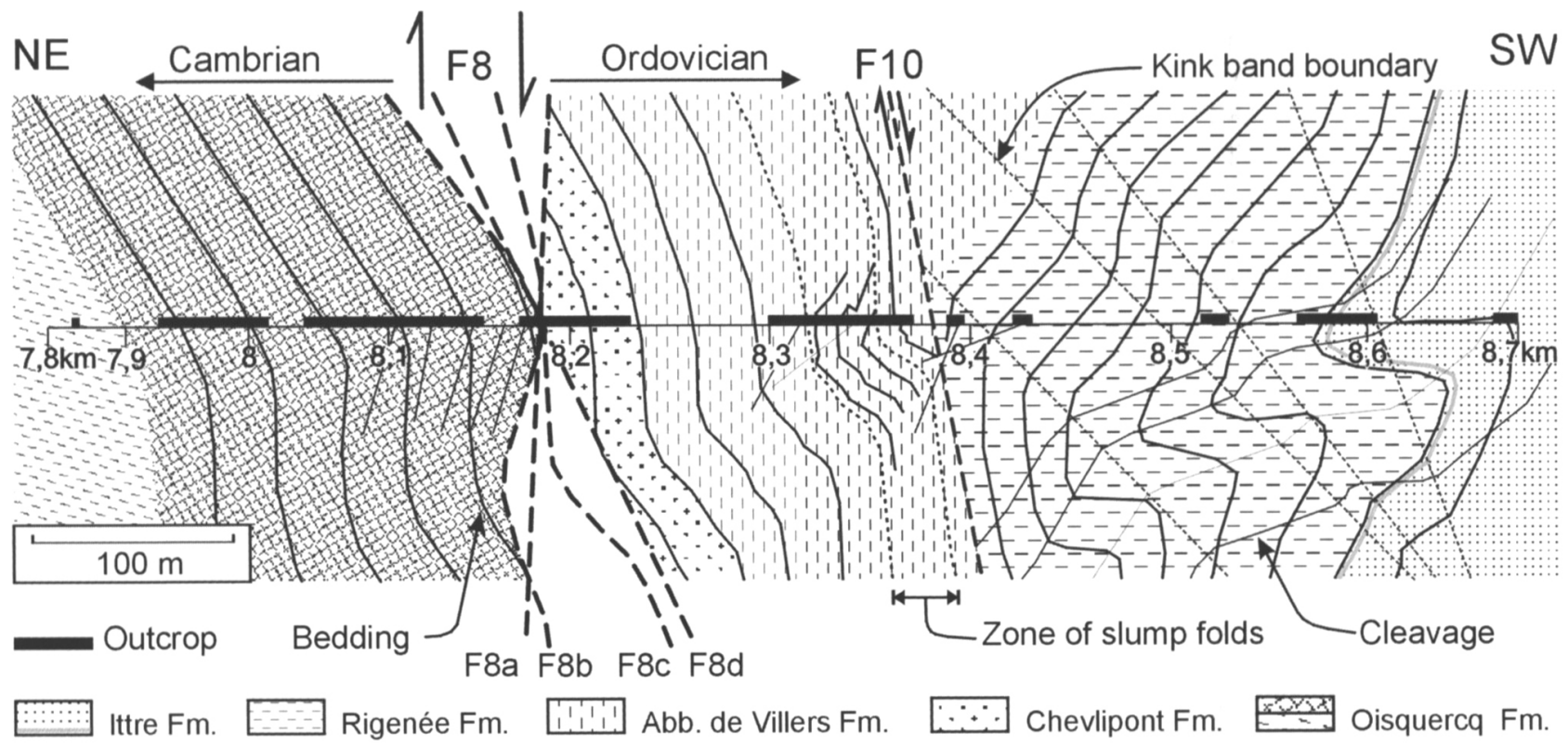

Fig. 9. Cross-section along the Virginal railway section (see Fig. 4 for section line), showing the Cambrian-Ordovician limit (F8), with four possible traces (F8a and F8d assuming a post-folding origin, F8b and F8c assuming a pre-folding origin), the likely position of F10 (cf. Fig. 8), and the inferred large-scale kinking of bedding and cleavage. Outcrops are marked in black and distances are expressed in railway kilometres. 
encountered around $600 \mathrm{~m}$ (F11; Fig. 8). There, however, the pronounced semi-ductile deformation of the cleavage, combined with the abundance of localised post-cleavage crush breccias, and the width of the fault zone relative to the height of the outcrop, do not allow to determine the fault zone orientation. Small faults in this zone are steeply S-dipping and indicate a dip-slip down-throw towards the south.

\section{The Virginal railway section}

Although not as well exposed as the Bief 29 section, the Virginal railway section covers more formations and clearly shows the contact between the Lower to lower Middle Cambrian Oisquercq Formation and the lower Tremadoc Chevlipont Formation (Fig. 9, see Fig. 4 for location).

\section{The contact between the Cambrian and the Ordovician: F8}

This contact consists of a several metre-wide zone in which lenses of the Chevlipont Formation are repeatedly encountered in between rocks of the Oisquercq Formation and vice versa. An important difference with the faults along the Bief 29 section and the central Asquempont section is the absence of post-cleavage fault fabrics and semi-ductile cleavage deformation. In outcrop and on cut hand specimens the cleavage can be seen cross-cutting the boundaries between the fragments of the two different formations (cf. Fig. 7B). Hence, faulting pre-dates cleavage. Several planes with (dip-slip) striations are present. However, these are not restricted to this fault zone, and since they crosscut the cleavage they are not considered related to $\mathrm{F} 8$.

The orientation of this fault zone is difficult to determine. A comparison of the position of the fault zone in both railway trenches points to a strike of $320^{\circ}$ to $330^{\circ}$, oblique to the cleavage. In outcrop, the fault zone appears to be steeply dipping. However, because of the small height of the outcrop in comparison to the width of this fault zone, the overprint of the steeply to moderately NE-dipping cleavage and the absence of measurable pre-cleavage fault planes, the exact dip and the cut-off angle with bedding remain uncertain (Fig. 9).

\section{Large-scale kink band}

By analogy with the Bief 29 section, the change in cleavage orientation in the Rigenée Formation and the lower part of the Ittre Formation in the southern part of the section is interpreted as a large-scale kink band with steeply SW-dipping kink band boundaries (Fig. 9). It should be taken into account that because of the scarcity of outcrops this part of the section is not very well constrained. Nevertheless, the observations suggest that the apparent width of the kink band is larger than in the Bief 29 section and that not one but two large-scale kink bands seem to be present. Either this is a result of faulting (F11?) or a result of kink band bifurcation (cf. Dubey \& Cobbold, 1977).

\section{Fault fabric}

\section{Fault zone F7}

The foliated rock in fault zone F7 consists of an alternation of dark-coloured quartz-rich bands with a large amount of opaque material and beige to palegrey phyllosilicate-rich bands. The bands are usually 0.5 to 5 millimetres thick. At first sight this particular disposition shows resemblance to a fabric resulting from metamorphic differentiation, i.e. a pressure solution-related preferential concentration of quartz on the one hand and mica on the other hand, giving rise to quartz and mica bands at high angles to the original, destroyed fabric (see Cosgrove, 1976; Price \& Cosgrove, 1990). However, although often having an ondulose extinction and showing evidence of recrystallisation, the detrital nature of the quartz grains is still recognisable. In addition, in general these quartz grains do not show a preferred elongation and strain shadows have not been observed. Hence, these quartz-rich bands most likely reflect bedding. The phyllosilicate-rich bands almost entirely consist of white mica and chlorite-mica stacks, with a preferred alignment sub-parallel to the sub-vertical foliation. Within these phyllosilicate bands a disjunctive cleavage occurs, with microlithons generally 25 to $50 \mathrm{mi}-$ crons wide. This steeply NE-dipping cleavage occurs at a very small angle $\left(<30^{\circ}\right)$ to the sub-vertical foliation reflected by the banding. This disposition is identical to the disposition of bedding and cleavage in the unnamed unit, directly south of F7 (cf. Fig. 5).

Throughout the small folds within F7, the angle between cleavage and bedding remains the same. Hence, these folds post-date cleavage. Within these folds, both along cleavage and along bedding planes, small curved slip planes occur, reflecting a downthrow to the north. This sense of movement also becomes apparent from small displacements of millimetre-scale, quartz-infilled fractures oriented at high angles to the bedding in the sub-vertical limbs of the small folds.

The larger veins in F7, cross-cutting the foliation and the folds, contain a quartz and carbonate infill, with occasionally some chlorite. Locally the relatively undeformed carbonate takes up the largest portion of the veins, acting as a matrix for the deformed quartz crystals. These veins are deformed by small normal 
faults, running sub-parallel to the foliation, with a down-throw to the south.

\section{Fault F8}

Like the macroscopic observations on oriented hand specimens, also microscopic observations indicate that this fault did not form after cleavage development. The fault rock consists of a mixture of fragments of greenish-grey mudstone of the Oisquercq Formation, rich in white mica, and dark grey mudstone and pale-coloured siltstone to fine-grained sandstone of the Chevlipont Formation or the unnamed unit. The limits between the different fragments are crosscut by the cleavage and pressure solution seams occur around the more competent (Ordovician) fragments, indicating that they were isolated bodies prior to cleavage development. Furthermore, the cleavage does not show evidence of deformation. The only changes in cleavage orientation are due to cleavage refraction. Thin sections from F8 in the central Asquempont section occasionally show small quartz veins cross-cutting the cleavage. Because these veins do not occur in F8 in the Virginal railway section, post-date the cleavage and do not show a relationship with the contacts between the different lithologies inside $\mathrm{F} 8$, they are considered related to the nearby presence of $\mathrm{F} 7$.

\section{Discussion}

\section{Correlation across the study area}

Three types of faults are recognised, two of which postdate cleavage development. F8, pre-dating cleavage development, is encountered in the Virginal railway section (Fig. 9), the central Asquempont section (Fig. 5) and in outcrop Rue de l'ancien canal 1, at the $\mathrm{N}$-side of the eastern end of the old canal (Bief 29, see Fig. 4 for location). Since this fault represents the 'true' Cambrian-Ordovician contact, we define her as the Asquempont fault, by analogy with Legrand (1967).

Of the post-cleavage faults, the reverse faults, as encountered along the Bief 29 section (F9, Fig. 8), seem the least important, both in occurrence as in amount of displacement. In contrast, numerous post-cleavage steeply $\mathrm{N}$ - and S-dipping normal faults occur. Of these, F7, wrongly considered to form the CambrianOrdovician contact by Legrand (1967), probably has the largest displacement (see below). The normal fault zone F10, encountered in the Bief 29 section, can be traced towards the east, running in between outcrops Virginal railway section 2 and 3, and towards the west, in between outcrops Rue de l'ancien canal 2 and 3 (Fig. 4).

The large-scale kink band can easily be correlated between the Virginal railway section and the Bief 29 section. Towards the east, parts of it are encountered in outcrop Rue de l'ancien canal 3. The northern part of this kink band shows striking similarities with the post-cleavage overturning encountered in outcrop central Asquempont section 2. There, F7 truncates this kink band, suggesting that F7, like F10 and F11 in the Bief 29 section, formed after kink band development.

A geological map of the area was constructed taking into account all the observations, and keeping the number of faults as low as possible (Fig. 10). A significant repetition of the Ordovician formations becomes apparent. The only candidate for this repetition is F7. The structural observations and the stratigraphic distribution indicate a down-throw to the north, with an estimated amount of displacement between 700 and $1000 \mathrm{~m}$.

Although outcrop central Asquempont section 2 shows a juxtaposition of the Chevlipont Formation and the Oisquercq Formation (F8, Fig. 5), the cartographic distribution of the different rock units suggests that at this locality F8 forms the contact between the Oisquercq Formation and the Rigenée Formation or the Ittre Formation (Fig. 10). This is compatible with observations of previous researchers (Dumont, 1848; Malaise, 1873, 1908), who describe, close to the lock along the old canal (presently situated in the middle of the new canal), a deformed zone of dark grey to black rocks (i.e. Ordovician), containing magmatic levels, adjacent to greenish rocks (i.e. Oisquerq Formation). On the basis of Primitia simplex, Malaise (1908) considered the former rocks as 'Llandeilo', which is now upper Llanvirn-lower Caradoc. Corin (1963) determined the fine-grained volcanic nature of the magmatic rocks. To our knowledge, the only volcanic rocks in this area are situated in the lower part of the middle Caradoc Ittre Formation (cf. Debacker et al., 2001; Verniers et al., 2001). Taking into account the large width of F8 in the Virginal railway section, this apparent discrepancy (Chevlipont Formation in outcrop versus Ittre/ Rigenée Formation on map) may be explained by arguing that along the central Asquempont section the outcropping four square metres of the Chevlipont Formation below F8, does in fact represent a lens of Tremadoc rocks trapped in F8.

Judging from the relative orientation of $\mathrm{F} 8$ and the different post-cleavage faults on the map, it appears that, outside of the large-scale kink band, F8 is subvertical to steeply NE-dipping, which corresponds well with the observations in the Virginal railway section (cf. Fig. 9). The apparent strike of this fault $\left(320^{\circ}-330^{\circ}\right)$ is oblique to bedding and cleavage. 


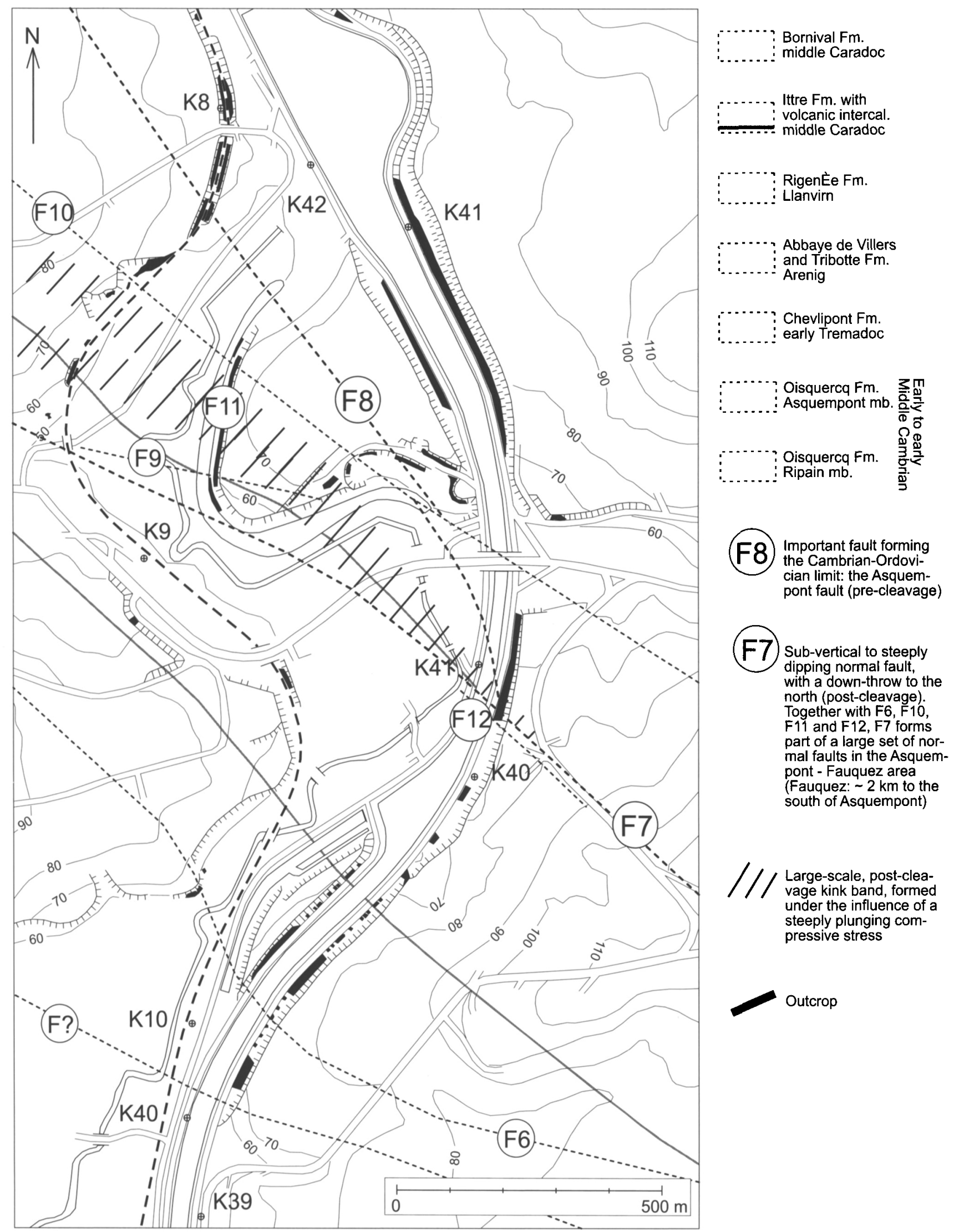

Fig. 10. Geological map of the Asquempont area. The repetition of the Upper and Middle Ordovician beds is attributed to F7, whereas the Cambrian-Ordovician contact is formed by F8. Note the exceptional position of the classical outcrop of the Asquempont fault, situated at the junction of three large, apparently unrelated structural features: F8, F7 and the large-scale kink band. 


\section{Relative age of the different structures}

The orientation of the $\mathrm{N}$ - and S-dipping post-cleavage normal faults (F6, F7, F10, F11, F12) reflects an extensional setting (steeply plunging maximum compressive stress), suggesting fault initiation after the main compressive deformation. As indicated by the faulted protocataclasites and the locally occurring deformed veins with a broken quartz infill, these faults experienced several episodes of movement. Some of these faults (F7, F12) experienced relatively high fluid pressures, both during the early stages of move-

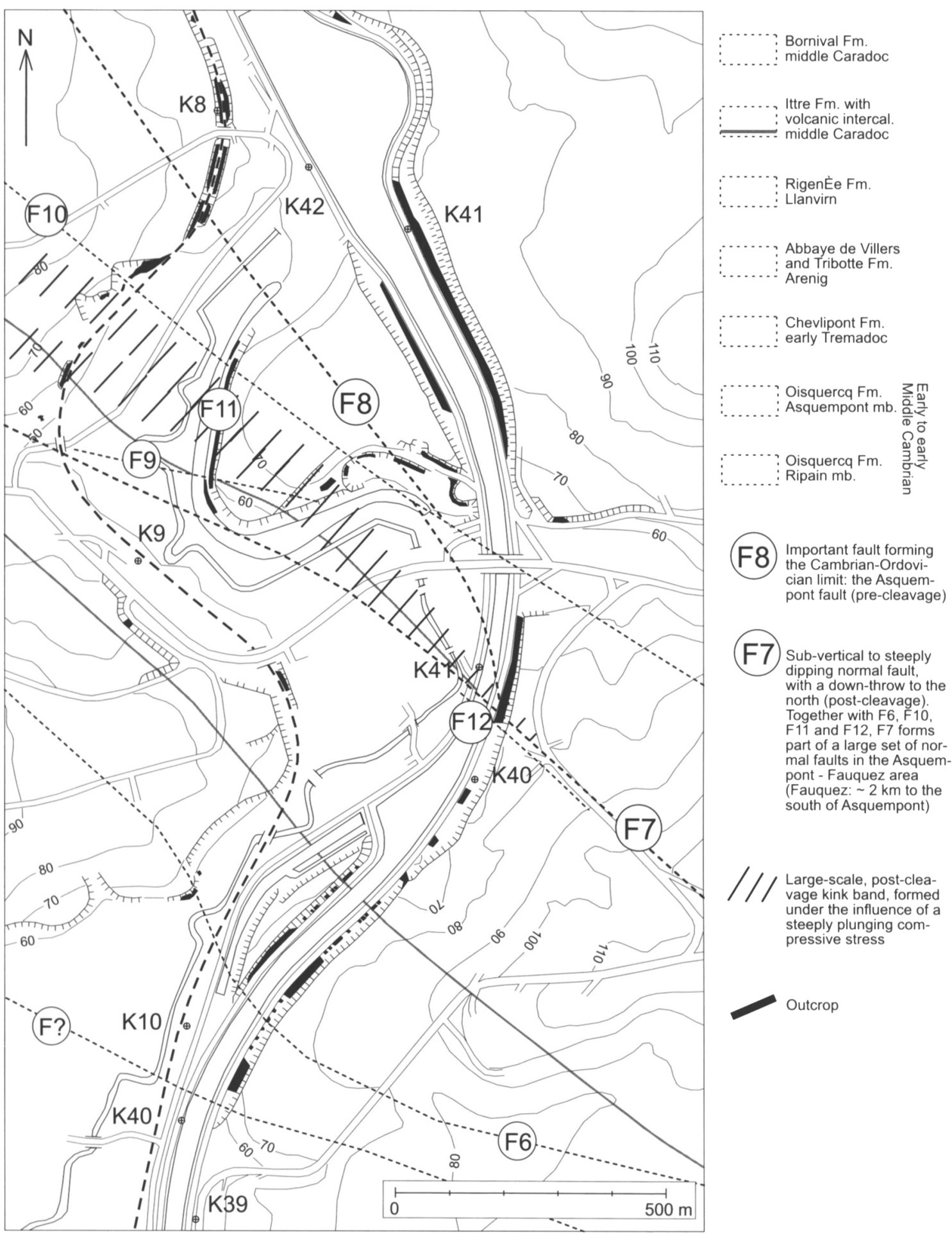

Fig. 11. Schematic representation of the nature and position of the Cambrian-Ordovician contact along the E-side of the railway in the Quenast area, Senne valley, to the north of the Quenast plug (cf. Fig. 12). Distances are expressed in railway kilometres. Note the repetition of the different rock units, crosscut by the cleavage. 


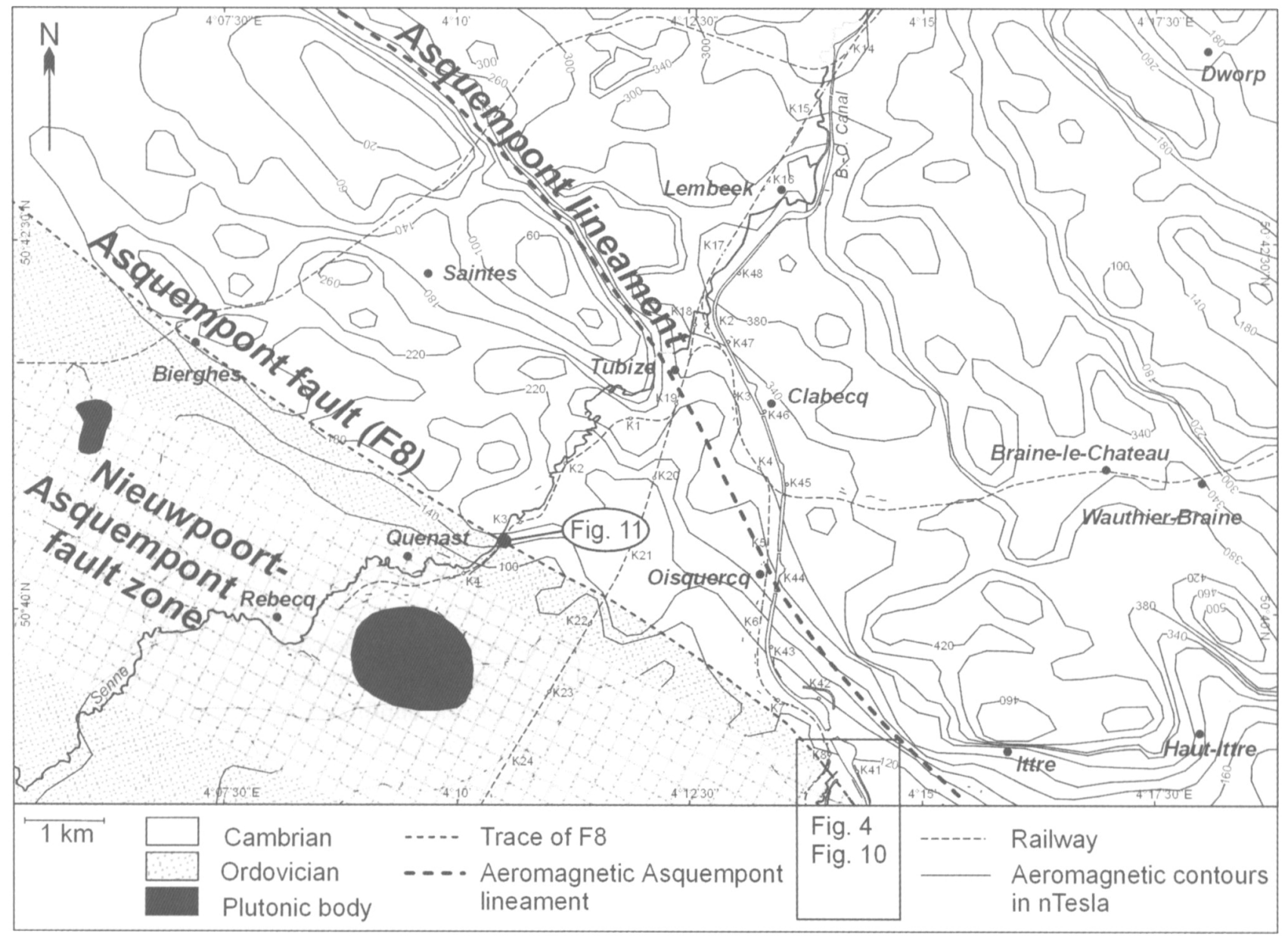

Fig. 12. Simplified topographic map of the Rebecq-Ittre area, showing the aeromagnetic contours (taken from Belgian Geological Survey, 1994), the trace of the aeromagnetic Asquempont lineament (cf. Fig. 1 and Fig. 13), the probable trace of the Asquempont fault (F8) between the Asquempont area to the SE (cf. Fig. 10) and the Quenast area to the NW (cf. Fig. 11), and the several kilometres wide zone of normal faults between Bierghes and Asquempont, apparently forming the southeastern extension of the Oudenaarde-Bierghes fault zone, which was incorporated in the Nieuwpoort-Asquempont fault zone by De Vos et al. (1993a; cf. Everaerts et al., 1996; Sterpin \& De Vos, 1996). The trace of the Asquempont fault to the NW of Quenast is based on the distribution of Cambrian and Ordovician deposits depicted on the geological map of De Vos et al. (1993a), slightly corrected with the aid of unpublished borehole data. Note the discrepancy in orientation and position between the Asquempont fault and the Asquempont lineament.

ment (quartz veins) and during the later stages of movement (carbonate infill). The large-scale kink band, of which the geometry is compatible with the orientation of the principal stress axes responsible for normal faulting (cf. Paterson \& Weiss, 1966, Price \& Cosgrove, 1990), probably formed slightly before or during the early stages of normal faulting. Possibly, some of the normal faults developed preferentially along zones of weakness generated by the large-scale kink band.

The reverse fault F9 (Fig. 8, Fig. 10), of which movement post-dates cleavage development, formed during compression. Its particular disposition along an antiformal hinge zone may suggest fault initiation related to fold development.

At present, not taking into account the few welded faults related to slumping (e.g. Debacker et al., 2001),
F8 appears to be the only known pre-cleavage fault in the Brabant Massif (cf. Fourmarier, 1921; Legrand, 1967; Debacker et al., 1999, 2001; Belmans, 2000; Debacker, 2001, 2002). In the Brabant Massif cleavage is considered to have formed cogenetically with folding (Sintubin et al., 1998; Sintubin, 1997a, 1999; Debacker et al., 1999, 2001, 2002; Debacker, 2001). Therefore, since F8 pre-dates cleavage development, it should also pre-date folding.

Correlation with other outcrop areas and boreholes: nature and age of the faults

\section{The Asquempont fault, F8}

Along the railway in the Quenast area, Senne valley, situated a few kilometres to the west of the Sennette valley, a steeply dipping pre-cleavage tectonic contact 


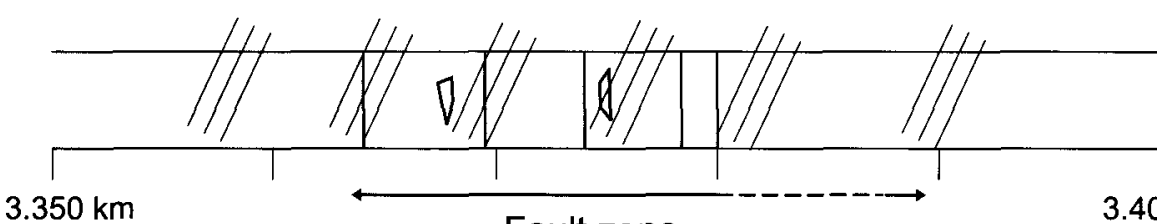

\section{$3.400 \mathrm{~km}$}

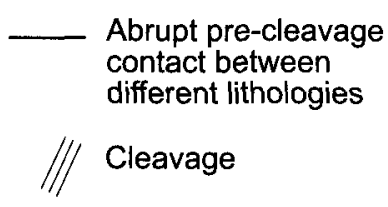

Fault zone

Chevlipont or Abb. de Villers Fm. (Lower/Middle Ordovician)

Abbaye de Villers Fm. (lower Middle Ordovician)
Oisquercq Fm.

(Lower to lower Middle Cambrian)

Fig. 13. Part of the aeromagnetic map of Belgium, reduced to the pole with a pseudo-illumination from the northeast (De Vos et al., 1993b; cf. Chacksfield et al., 1993), showing the most pronounced aeromagnetic lineaments (traced in white), the trace of the Asquempont lineament (cf. Fig. 1; De Vos et al., 1993a), the trace of the aeromagnetic lineament associated with the Nieuwpoort-Asquempont fault zone (cf. Fig. 1; De Vos et al., 1993a), the position of the study area and of several outcrop and borehole localities in which a tectonic contact is encountered between Cambrian and Ordovician formations that strongly resembles the Asquempont fault (F8). Belgian Lambert coordinates are added for a better orientation (cf. Fig. 1).

occurs between steeply dipping beds of the Oisquercq Formation to the north and the Chevlipont/Abbaye de Villers Formation to the south (Fig. 11, Fig. 12) (cf. Vanguestaine, 1977; Lenoir, 1987). The nature of this contact is practically identical to that of the Asquempont fault in the Virginal railway section in the Sennette valley.

In the unexposed areas to the west of Quenast, several boreholes show sub-horizontal to gently dipping Ordovician and Cambrian deposits, separated by a pre-cleavage contact zone strongly resembling F8 (see Fig. 1 \& Fig. 13 for location). At Bever (borehole 383DB1) sub-horizontal Upper Ordovician rocks (probably Caradoc; dated biostratigraphically with chitinozoans; Verniers, unpub. data) are separated by a sub-horizontal zone of pre-cleavage deformation (Debacker, 1998) from underlying deposits of the Oisquercq Formation. In the Lessines borehole, the sub-horizontal contact between sub-horizontal sediments of the Lower Ordovician Chevlipont Formation and the underlying Lower to lower Middle Cambrian Oisquercq Formation, originally described as a "micro-conglomerate" by Herbosch et al. (1991), shows very strong similarities with F8. A similar contact between Ordovician rocks and underlying Lower to lower Middle Cambrian rocks has also been observed in boreholes at Schendelbeke and Waregem (De Vos, pers. comm. 1999).

Provided the correlation between the tectonic contacts observed in outcrops and boreholes is valid, it appears that $\mathrm{F} 8$ not only pre-dates cleavage, but, as expected, also pre-dates folding. More importantly, since this fault places younger deposits on top of older deposits, it is a normal fault instead of a reverse fault. Hence, the Asquempont fault, F8, can be regarded as a pre-cleavage and pre-folding low-angle extensional detachment.

In the Asquempont-Virginal area, the youngest beds cut by F8 appear to belong to the Rigenée Formation or the base of the Middle Caradoc Ittre Formation. In the Bever borehole the deposits directly above the Oisquercq Formation are of Late Ordovician age, probably Caradoc. As such, movement along $\mathrm{F} 8$ can be confined to the period spanning the Caradoc to the time of cleavage and fold development.

\section{Large post-cleavage normal faults}

Although a certain bias may be present due to the degree of exposure and the time spent studying the different outcrop areas, important, steeply dipping, post-cleavage normal faults like those encountered in the $\sim 3 \mathrm{~km}$ wide zone in the Sennette valley between the Asquempont-Virginal area to the north and the Fauquez area to the south (cf. Debacker et al., 2001; Debacker, 2001; Van Grootel et al., 2002) appear to be rather scarce in the outcrop areas to the east of the Sennette valley (Dyle, Orneau and Mehaigne valleys; Belmans, 2000; Debacker, 2001, 2002; Herbosch \& Lemonne, 2000; Herbosch et al., 2002). However, in the outcrop areas to the west of the Sennette valley similar, steeply dipping normal faults, often containing a quartz and/or carbonate infill, seem abundant (Fig. 12; cf. figs. $1 \& 13$ ). Several of these are present in the Senne valley in the surroundings of the Quenast plug (Debacker, 2001; Herbosch, unpub. data; cf. André \& Deutsch, 1985) and new observations indicate that also the presumed mylonitic strike-slip shear zones cross-cutting the sill at Bierghes (André \& Deutsch, 1985) are in fact steeply N-dipping normal faults, reactivating the pre-existing cleavage fabric. Also in the unexposed parts of the Brabant Massif, further to the WNW, numerous boreholes show brecciated rocks cemented by a quartz and/or carbonate matrix (Legrand, 1968). The WNW-ESE-trending zone of brecciation, apparent from these borehole observa- 
tions, was labelled the Oudenaarde-Bierghes fault zone by Legrand (1968). On the basis of geophysical data and stratigraphic jumps inferred from borehole data, De Vos et al. (1993a) extended this fault zone towards the east and towards the west and labelled it the Nieuwpoort-Asquempont fault zone. The apparent scarcity of important normal post-cleavage faults to the east of the Sennette valley, the similarity and parallelism between these faults in the study area and those at Bierghes and Quenast, and the alignment of these three outcrop areas, lying in the eastward extension of the Oudenaarde-Bierghes fault zone (Fig. 12, Fig. 13), suggests that these faults may form part of the same large fault zone, i.e. the eastern part of the Nieuwpoort-Asquempont fault zone of De Vos et al. (1993a).

Based on poor, indirect evidence from the Bierghes sill, André \& Deutsch (1985) put forward a strike-slip movement of unknown sense and amount of displacement along parts of the Oudenaarde-Bierghes fault zone. This idea was shared by Everaerts et al. (1996) and Sterpin \& De Vos (1996), who, on the basis of aeromagnetic, geochemical, hydrochemical and AFMAG lineaments in the unexposed parts of the Brabant Massif, interpreted the Nieuwpoort-Asquempont fault zone as the mean shear plane of a sinistral Riedel system and hence concluded a sinistral sense of movement. However, the absence of strike-slip indicators in outcrop and the consistent normal sense of movement along the observed faults are difficult to reconcile with this supposed strike-slip movement.

The nature of the large normal post-cleavage faults (quartz veins, semi-ductile cleavage deformation) suggests development at a certain depth. Hence, considering the Late Palaeozoic and younger history of the Brabant Massif (cf. Patijn, 1963; Van den haute \& Vercoutere, 1989), it does not seem likely that these faults originated after the Givetian unconformity. This pre-unconformity initiation is compatible with the Lochkovian to Namurian age of normal faulting in the eastern part of the Brabant Massif (Poty, 1991), can be reconciled with the $\mathrm{Rb}-\mathrm{Sr}$ isotope resettings between the middle Eifelian and the late Frasnian (time-scale of Gradstein \& Ogg, 1996), considered to mark movements along parts of the Oudenaarde-Bierghes fault zone (André \& Deutsch, 1985), and also matches the data from Ronquières, four kilometres to the south of the study area, where normal faults formed prior to the Givetian conglomerate deposition (Debacker et al., 1999) as well as during and after deposition of the Givetian (Legrand, 1967; Debacker et al., 1999). As evidenced by outcrop observations many of these normal faults were later reactivated. According to hydrochemical studies (Sterpin \&
De Vos, 1996) and recent earthquakes (Camelbeeck, 1993, 1997) parts of the Nieuwpoort-Asquempont fault zone are still active (cf. De Vos, 1997).

\section{Comparison with aeromagnetic data}

Although in the Asquempont-Virginal area both traces seem parallel, the trace of F8, the Asquempont fault, as defined in this paper, is situated $1.5 \mathrm{~km}$ to the southwest of the pronounced aeromagnetic Asquempont lineament (Fig. 12). It might be argued that this is compatible with the steep NE-dip of the Asquempont fault: since the aeromagnetic lineament corresponds to the position of the fault at depth it shows up to the northeast of the fault outcrop trace. However, a larger-scale picture demonstrates that both features are unrelated. When the outcrop position of F8 in the Senne valley is taken into account, an apparent trace of approximately $300^{\circ}-120^{\circ}$ is obtained (figs. $12 \& 13$ ), coinciding with the trace of the Virginal fault drawn by Mortelmans (1955; cf. Beugnies in Waterlot et al., 1973). This trace is oblique to that of the aeromagnetic Asquempont lineament. Furthermore, when also the borehole data (e.g. Lessines, Bever, Waregem, Schendelbeke) are incorporated (Fig. 13), it becomes clear that F8 cannot be related to this aeromagnetic lineament.

Between Asquempont and Quenast and extending some $10 \mathrm{~km}$ further to the northwest, the mapped trace of the Asquempont fault apparently coincides with a very weak aeromagnetic lineament (Fig. 12). Considering the inferred low cut-off angle with bedding, the pre-folding nature of the Asquempont fault and the presence of a rather thick mass of rocks of the Oisquercq Formation in the footwall of this fault, having comparable to only slightly higher magnetic susceptibilities than those of the Ordovician rocks in the hanging wall (De Vos et al., 1992), the aeromagnetic gradient associated with the contact between these lithologies is indeed expected to be very weak, if visible at all.

The Oudenaarde-Bierghes fault zone (Legrand, 1968; André \& Deutsch, 1985) coincides with a segment of a relatively wide, irregular, WNW-ESE-trending aeromagnetic and gravimetric lineament running from Asquempont to Nieuwpoort (Fig. 13, cf. Fig. 1, Fig. 12), called the Nieuwpoort-Asquempont fault zone by De Vos et al. (1993a; cf. Chacksfield et al., 1993). The large normal post-cleavage faults encountered in the Asquempont-Virginal-Fauquez area, those from the Quenast area and the Bierghes sill and the brecciations of the Oudenaarde-Bierghes fault zone all lie within the zone occupied by this geophysical lineament, thus supporting the correlation between the observed normal faults and the eastern part 


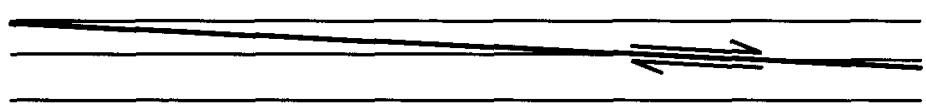

3. Kink band development in the northern limb of the 2. Folding and cleavage

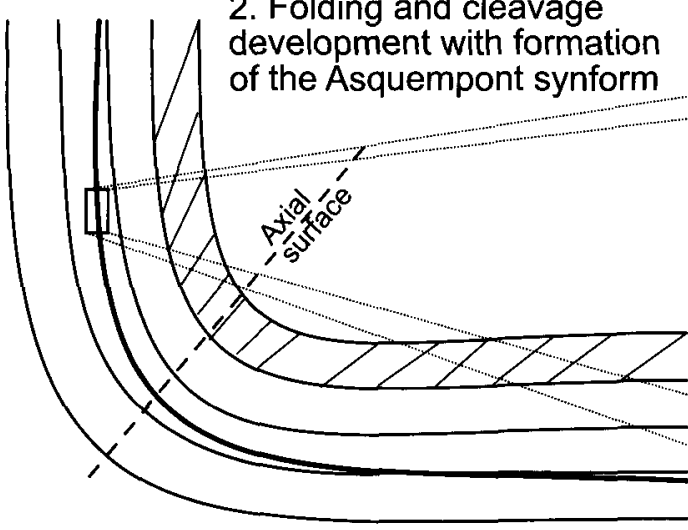

Asquempont synform

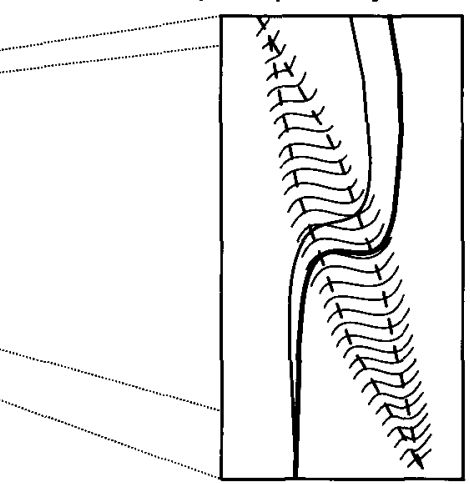

4. Development of F7, displacing both the kink band and F8

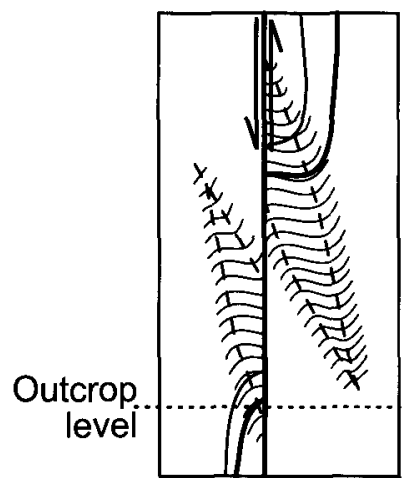

Fig. 14. Schematic representation of the consecutive development of 1) the Asquempont fault as defined in this study (F8), 2) folding and cleavage (e.g. the Asquempont synform, Debacker $e t$ al., 2001), 3) the large-scale kink band and 4) the steep normal fault F7, thus offering an explanation for the structural complexity of the classical outcrop of the Asquempont fault and the Asquempont-Virginal area.

of the Nieuwpoort-Asquempont fault zone. However, although locally strike-slip movements may have occurred along this fault zone, our observations suggest that at least its eastern part essentially consists of $\mathrm{N}$ and S-dipping, post-cleavage normal faults.

\section{Conclusions}

Although many researchers have advocated the importance of reverse and strike-slip faults in the SenneSennette outcrop area and further to the west (e.g. Mortelmans, 1955; Legrand, 1967; André \& Deutsch, 1985, Sterpin \& De Vos, 1996; Everaerts et al., 1996; Hennebert \& Eggermont, 2002), new outcrop observations from the Senne-Sennette valley, in particular from the Asquempont-Virginal area, "type locality" of the Asquempont fault, indicate that the most important faults appear to be normal faults.

In the area between Fauquez, Asquempont-Virginal, Quenast and Bierghes, a large number of steep, $\mathrm{N}$ - and S-dipping post-cleavage and post-folding normal faults are encountered. At least several of these originated prior to deposition of the Givetian conglomerates and many experienced reactivation. These large normal faults most likely form part of the WNW-ESE-trending Nieuwpoort-Asquempont fault zone. At present, there is no kinematic evidence for strike-slip movements along this fault zone.

In contrast to the opinion of Legrand (1967), the real contact between the Lower to lower Middle Cambrian and the Ordovician in the Asquempont area is formed by a several $\mathrm{m}$-wide pre-cleavage fault (F8). Taking into account the classical definition of Legrand, (1967), it is this fault that we redefine herein as the Asquempont fault (F8). The Asquempont fault is not a reverse fault, but instead is a low-angle extensional detachment of which the activity can be confined to the period between the early Caradoc and the timing of folding and cleavage development. There is no relationship between the Asquempont fault and the aeromagnetic Asquempont lineament.

The structural complexity of the central Asquempont section, the classical outcrop of the Asquempont fault, and the resulting confusion concerning the nature of the Cambrian-Ordovician contact (cf. Legrand, 1967) is mainly due to its particular position, situated at the intersection between a large postcleavage normal fault (F7: the Asquempont fault of Legrand, 1967), the presently redefined Asquempont fault (F8) and a large-scale kink band (Fig. 14).

Possibly, the Asquempont fault originated during the early, Silurian stages of progressive basin inversion as a result of the unroofing of the rising and steepening Cambrian core of the Brabant Massif (Debacker, 2001, Sintubin \& Everaerts, 2002, Verniers et al. 2002, Debacker et al., 2002, Sintubin et al., 2002). According to this hypothesis, similar lowangle extensional detachments might also be expect- 
ed in the northern part of the Brabant Massif. On the geological map of De Vos et al. (1993a), a number of unexplained contacts are shown, resembling paraconformities or low-angle unconformities (see Fig. 1). As shown in this paper, the contact between the Ordovician (Lower, Middle or Upper Ordovician) and the Lower to lower Middle Cambrian Oisquercq Formation in the southwestern part of the Brabant Massif can, at least partly, be attributed to the Asquempont fault. However, this contact is also shown in the northwestern part of the Brabant Massif and apparently continues towards the east, first as the limit between the Oisquercq Formation and the Middle to Upper Cambrian Mousty Formation, then as the limit between the lowermost Cambrian Tubize Formation and the Mousty Formation. Could also these contacts represent low-angle extensional detachments similar to the Asquempont fault?

\section{Acknowledgments}

W. De Vos is kindly acknowledged for communicating unpublished borehole data. We thank an anonymous reviewer for commenting on the manuscript. The first author is grateful to B. Vanhoecke for the numerous stimulating discussions. T. N. Debacker is a postdoctoral researcher of the Fund for Scientific ResearchFlanders (F.W.O.-Vlaanderen). M. Sintubin is a Research Associate of the Bijzonder Onderzoeksfonds, K.U.Leuven. Part of the work of A. Herbosch was sponsored by F.N.R.S. project 2.4506.97. This work forms part of research project G.0094.01 of the F.W.O.-Vlaanderen.

\section{References}

André, L. \& Deutsch, S., 1985. Very low-grade metamorphic Sr isotopic resettings of magmatic rocks and minerals: evidence for a late Givetian strike-slip division of the Brabant Massif, Belgium. Journal of the Geological Society, London 142: 911-923.

Belgian Geological Survey, 1994. Aeromagnetic map of the Brabant Massif: residual total field reduced to the pole. Scale $1 / 100000$.

Belmans, M., 2000. Structurele geologie van het Siluur uit de Orneauvallei, Massief van Brabant. Unpublished M.Sc. thesis, Laboratorium voor Paleontologie, Universiteit Gent.

Camelbeeck, T., 1993. Mécanisme au foyer des tremblements de terre et contraintes tectoniques: le cas de la zone intraplaque belge. Unpublished Ph.D. thesis, Université Catholique de Louvain.

Camelbeeck, T., 1997. The study of active faults in stable continental Europe: examples in the Roer Graben and in the Belgian seismic active zone. Aardkundige Mededelingen 8: 35-38.

Chacksfield, B., De Vos, W., D'hooge, L., Dusar, M., Lee, M., Poitevin, C., Royles, C. \& Verniers, J., 1993. A new look at Belgian aeromagnetic and gravity data through image-based display and integrated modelling techniques. Geological Magazine 130: 583-591.
Corin, F., 1963. Sur les roches éruptives de la tranchée d'Hasquempont, canal de Charleroi. Bulletin de la Société belge de Géologie, de Paléontologie et d'Hydrologie 72: 55-60.

Cosgrove, J.W., 1976. The formation of crenulation cleavage. Journal of the Geological Society, London 262: 153-176.

Debacker, T.N., 1998. Verslag boorbeschrijving van boring 383DB1 te Bever. Intern rapport in opdracht van het Ministerie van de Vlaamse Gemeenschap, Afdeling Natuurlijke Rijkdommen en Energie (ANRE), pp. 1-4.

Debacker, T.N., 1999. Folds trending at various angles to the transport direction in the Marcq area, Brabant Massif, Belgium. Geologica Belgica 2: 159-172.

Debacker, T.N., 2001. Palaeozoic deformation of the Brabant Massif within eastern Avalonia: how, when and why? Unpublished Ph.D. thesis, Laboratorium voor Paleontologie, Universiteit Gent.

Debacker, T.N., 2002. Cleavage/fold relationship in the Silurian of the Mehaigne-Burdinale area, southeastern Brabant Massif, Belgium. Geologica Belgica 5: 3-15.

Debacker, T.N., Sintubin, M. \& Verniers, J., 1999. Cleavage/fold relationships in the Silurian metapelites, southeastern Anglo-Brabant fold belt (Ronquières, Belgium). Geologie \& Mijnbouw 78: 47-56.

Debacker, T.N., Sintubin, M. \& Verniers, J., 2001. Large-scale slumping deduced from structural and sedimentary features in the Lower Palaeozoic Brabant Massif, Belgium. Journal of the Geological Society, London 158: 341-352.

Debacker, T.N., Sintubin, M. \& Verniers, J., 2002. Timing and duration of the progressive deformation of the Brabant Massif, Belgium. Aardkundige Mededelingen 12: 73-76.

de Magnée, I. \& Raynaud, J., 1944. Etude magnétique de la tectonique du Cambrien du Brabant à l'est de Court-St-Etienne. Annales de la Société Géologique de Belgique 67: 495-546.

De Vos, W., 1997. Influence of the granitic batholith of Flanders on Acadian and later deformation (Brabant Massif, Belgium). Aardkundige Mededelingen 8: 49-52.

De Vos, W., Chacksfield, B.C., D'Hooge, L., Dusar, M., Lee, M.K., Poitevin, C., Royles, C.P., Vandenborgh, T., Van Eyck, J. \& Verniers, J., 1993b. Image-based display of Belgian digital aeromagnetic and gravity data. Professional Paper of the Geological Survey of Belgium 263: 1-8.

De Vos, W., Poot, B., Hus, J. \& El Khayati, M., 1992. Geophysical characterization of lithologies from the Brabant Massif as a contribution to gravimetric and magnetic modelling. Bulletin de la Société belge de Géologie 101: 173-180.

De Vos, W., Verniers, J., Herbosch, A. \& Vanguestaine, M., 1993a. A new geological map of the Brabant Massif, Belgium. Geological Magazine 130: 605-611.

Dubey, A.K. \& Cobbold, P.R., 1977. Non-cylindrical, flexural slip folds in nature and experiment. Tectonophysics 38: 223-239.

Dumont, A., 1848. Mémoire sur les terrains ardennais et rhénan de l' árdenne, du rhin, du brabant et du condros, seconde partie: terrain rhénan. Mémoires couronnés de l'Académie royale de Belgique, Classe des Sciences 22: 451 pp.

Everaerts, M., Poitevin, C., De Vos, W. \& Sterpin, M., 1996. Integrated geophysical/geological modelling of the western Brabant Massif and structural implications. Bulletin de la Société belge de Géologie 105: 41-59.

Fourmarier, P., 1914. La poussée calédonienne dans le massif siluro-cambrien du Brabant. Annales de la Société Géologique de Belgique 41: B300-314.

Fourmarier, P., 1921. La tectonique du Brabant et des régions voisines. Mémoires de l'Académie Royale de Belgique, Classe des Sciences (2ème série) 4: $95 \mathrm{pp}$.

Goscombe, B.D., Findlay, R.H., McClenaghan, M.P. \& Everard, J., 
1994. Multiscale kinking in northeast Tasmania - crustal shortening at shallow crustal levels. Journal of Structural Geology 16 : 1077-1092.

Gradstein, F.M. \& Ogg, J., 1996. A Phanerozoic time scale. Episodes 19: 3-6.

Hennebert, M. \& Eggermont, B., 2002. Carte Braine-le-Comte Feluy $n^{\circ} 39 / 5-6$, Carte géologique de Wallonie, échelle 1/25000. Ministère de la Région Wallonne (Namur).

Herbosch, A. \& Lemonne, E., 2000. Carte Nivelles-Genappe $n^{\circ}$ 39/7-8, Carte géologique de Wallonie, échelle 1/25000. Ministère de la Région Wallonne (Namur).

Herbosch, A., Vanguestaine, M., Degardin, J.M., Dejonghe, L., Fagel, N. \& Servais, T., 1991. Etude lithostratigraphique, biostratigraphique et sédimentologique du sondage de Lessines (bord méridional du Massif du Brabant, Belgique). Annales de la Société géologique de Belgique 114: 195-212.

Herbosch, A., Verniers, J., Debacker, T., Billiaert, B., De Schepper, S. \& Belmans, M., 2002. The Lower Palaeozoic stratigraphy and sedimentology of the Brabant Massif in the Dyle and Orneau valleys and of the Condroz Inlier at Fosses: an excursion guidebook. Geologica Belgica 5: 71-142.

Johnson, T.E., 1991. Nomenclature and geometric classification of cleavage-transected folds. Journal of Structural Geology 13: 261274.

Legrand, R., 1967. Ronquières, documents géologiques. Mémoires pour servir à l'Explication des Cartes Géologiques et Minières de la Belgique 6: 60 pp.

Legrand, R., 1968. Le Massif du Brabant. Mémoires pour servir à l'Explication des Cartes Géologiques et Minières de la Belgique 9: $148 \mathrm{pp}$.

Legros, B., 1991. Etude structurale du Cambro-Ordovicien de la vallée de la Sennette (Massif du Brabant) - Belgique. Unpublished M.Sc. thesis, Université Catholique de Louvain.

Lenoir, J.L., 1987. Etude cartographique, pétrographique et palynologique de l'Ordovicien inférieur du bassin de la Senne. Unpublished M.Sc. thesis, Université Libre de Bruxelles, Bruxelles.

Malaise, C., 1873. Description du terrain silurien du centre de la Belgique. Mémoires couronnés de l'Académie royale de la Belgique, Classe des Sciences 37: 122 pp.

Malaise, C., 1908. Compte rendu de l'excursion silurienne du 21 mai 1903. Bulletin de la Société Belge de Géologie 22: 59-62.

Mansy, J.L., Everaerts, M. \& De Vos, W., 1999. Structural analysis of the adjacent Acadian and Variscan fold belt in Belgium and northern France from geophysical and geological evidence. Tectonophysics 309: 99-116.

Mortelmans, G., 1955. Considérations sur la structure tectonique et la stratigraphie du Massif du Brabant. Bulletin de la Société belge de Géologie, de Paléontologie et d'Hydrologie 64: 179218.

Paterson, M.S. \& Weiss, L.E., 1966. Experimental deformation and folding in phyllite. Geological Society of America Bulletin 77: 343-374.

Patijn, R.J.H., 1963. Het Carboon in de ondergrond van Nederland en de oorsprong van het Massief van Brabant. Geologie \& Mijnbouw 42: 341-349.

Poty, E., 1991. Tectonique de blocs dans le prolongement oriental du Massif du Brabant. Annales de la Société géologique de Belgique 114: 265-275.

Price, N.J. \& Cosgrove, J.W., 1990. Analysis of geological structures. Cambridge University Press (Cambridge): 502 pp.

Samuelsson, J. \& Verniers, J., 2000. Ordovician chitinozoan biozonation of the Brabant Massif, Belgium. Review of Palaeobotany and Palynology 113: 105-129.

Servais, T., Vanguestaine, M. \& Herbosch, A., 1993. Review of the stratigraphy of the Ordovician in the Brabant Massif, Belgium.
Geological Magazine 130: 699-710.

Sintubin, M., 1997a. Cleavage-fold relationships in the Lower Palaeozoic Brabant Massif (Belgium). Aardkundige Mededelingen 8 : 161-164.

Sintubin, M., 1997b. Structural implications of the aeromagnetic lineament geometry in the Lower Palaeozoic Brabant Massif (Belgium). Aardkundige Mededelingen 8: 165-168.

Sintubin, M., 1999. Arcuate fold and cleavage patterns in the southeastern part of the Anglo-Brabant fold belt (Belgium): tectonic implications. Tectonophysics 309: 81-97.

Sintubin, M. \& Everaerts, M., 2002. A compressional wedge model for the Lower Palaeozoic Anglo-Brabant Belt (Belgium) based on Potential Field Data. In: Winchester, J., Verniers, J. \& Pharaoh, T. (Eds): Palaeozoic Amalgamation of Central Europe. Geological Society, London, Special Publications 201: 327-343.

Sintubin, M., Brodkom, F. \& Laduron, D., 1998. Cleavage/fold relationships in the Lower Cambrian Tubize Group, southeast Anglo-Brabant fold belt (Lembeek, Belgium). Geological Magazine 135: 217-226.

Sintubin, M., Debacker, T.N. \& Verniers, J., 2002. The tectonometamorphic history of the Brabant Massif (Belgium): the state of the art. Aardkundige Mededelingen 12: 69-72.

Sterpin, M. \& De Vos, W., 1996. Onderzoek naar metallische mineralisaties in de Paleozoïsche sokkel van Vlaanderen. Eindverslag Project VLA/94-3.5.: 47 pp.

Van den haute, P. \& Vercoutere, C., 1989. Apatite fission-track evidence for a Mesozoic uplift of the Brabant Massif: preliminary results. Annales de la Société Géologique de Belgique 112: 443452.

Van Grootel, G., Verniers, J. \& Debacker, T.N., 2002. Overview of the Upper Ordovician of the Fauquez area (Brabant Massif, Belgium), lithostratigraphy, biostratigraphy, geological map and structures. Aardkundige Mededelingen 12: 77-79.

Van Grootel, G., Verniers, J., Geerkens, B., Laduron, D., Verhaeren, M., Hertogen, J. \& De Vos, W., 1997. Timing of subsidence-related magmatism, foreland basin development, metamorphism and inversion in the Anglo-Brabant fold belt. Geological Magazine 134: $607-616$

Vanguestaine, M., 1977. Données palynologiques nouvelles dans l'Ordovicien inférieur du bassin de la Senne, Massif du Brabant, Belgique. Annales de la Société Géologique de Belgique 100: 223-231.

Vanguestaine, M., 1991. Datation par acritarches des couches Cambro-Trémadociennes les plus profondes du sondage de Lessines (bord méridional du Massif du Brabant, Belgique). Annales de la Société géologique de Belgique 114:213-231.

Verniers, J., Herbosch, A., Vanguestaine, M., Geukens, F., Delcambre, B. Pingot, J.L., Belanger, I., Hennebert, Debacker, T., Sintubin, M. \& De Vos, W., 2001. Cambrian-Ordovician-Silurian lithostratigraphical units (Belgium). Geologica Belgica 4: 5-38.

Verniers, J., Pharaoh, T., André, L., Debacker, T., De Vos, W., Everaerts, M., Herbosch, A., Samuelsson, J., Sintubin, M. \& Vecoli, M., 2002. Lower Palaeozoic basin development and Caledonian deformation history in and around Belgium in the framework of Eastern Avalonia. In: Winchester, J., Verniers, J. \& Pharaoh, T. (Eds): Palaeozoic Amalgamation of Central Europe. Geological Society, London, Special Publications 201: 47-93.

Waterlot, G., Beugnies, A. \& Bintz, J., 1973. Guides Géologiques Regionaux: Ardenne-Luxembourg. Masson et Cie. (Paris): 206 pp. 